\title{
Characteristics of Atmospheric Metalliferous Particles during Large-Scale Fireworks in Korea
}

\author{
Zang-Ho Shon, ${ }^{1}$ Ju-Hee Jeong, ${ }^{2}$ and Yoo-Keun Kim ${ }^{2}$ \\ ${ }^{1}$ Department of Environmental Engineering, Dong-eui University, Busan 614-714, Republic of Korea \\ ${ }^{2}$ Department of Atmospheric Sciences, Pusan National University, Busan 609-735, Republic of Korea \\ Correspondence should be addressed to Zang-Ho Shon; zangho@deu.ac.kr
}

Received 24 March 2015; Revised 3 June 2015; Accepted 10 June 2015

Academic Editor: Filomena Romano

Copyright (c) 2015 Zang-Ho Shon et al. This is an open access article distributed under the Creative Commons Attribution License, which permits unrestricted use, distribution, and reproduction in any medium, provided the original work is properly cited.

\begin{abstract}
The effect of large-scale firework events on urban background trace metal concentrations was investigated using $24 \mathrm{hr}$ data collected over 3 days at three sites in Busan Metropolitan City, Republic of Korea, during the falls (Oct.) of 2011-2013. The firework events increased local background concentrations of trace metals as follows: K (1.72 times), Sr (2.64 times), As (2.86 times), Pb (2.91 times), and $\mathrm{Al}$ (5.44 times). The levels of some metals did not always drop to background level one day after the firework event. The contribution of fireworks to trace metal concentration levels (and emissions) for 2011 event was negligible compared to 2012 and 2013 events due to different meteorological conditions (precipitation). In addition, the impact of firework events on the ambient concentration levels of trace metals was likely to be different depending on their chemical speciation. The impact of firework events in Busan on urban air quality (trace metal) was less intense compared to other similar festivals worldwide. The largest emission of trace metals and elements from firework burning was represented by $\mathrm{K}(128-164 \mathrm{~kg})$, followed by $\mathrm{Pb}, \mathrm{Cd}, \mathrm{Cu}, \mathrm{Mg}, \mathrm{Ba}, \mathrm{As}, \mathrm{Al}, \mathrm{Ga}$, $\mathrm{Co}$, and $\mathrm{Na}$.
\end{abstract}

\section{Introduction}

Enhancement of trace metal loading in the air is of great concern to air quality, as it adversely affects human health. Exposure to elevated concentrations of metals such as As, Cd, $\mathrm{Co}, \mathrm{Cr}, \mathrm{Ni}, \mathrm{Pb}$, and $\mathrm{Se}$ can cause cancer through inhalation of fine particles, although they constitute only a small fraction of the total particulate matter (PM) by mass $[1,2]$. Unlike continuous traffic emission, sporadic firework (crackers and sparkles) burning is one of the unique sources of airborne particles that include massive amounts of trace metals such as $\mathrm{Zn}, \mathrm{Ba}, \mathrm{Pb}, \mathrm{K}$, and $\mathrm{Sr}$ during a short period of time [3]. Fireworks also generate gaseous air pollutants such as $\mathrm{SO}_{2}, \mathrm{NO}_{x}\left(\mathrm{NO}+\mathrm{NO}_{2}\right)$, octachlorinated dioxins, furans, and hexachlorobenzene, including the primary emission of $\mathrm{O}_{3}$ without $\mathrm{NO}_{x}$ participation [3-6]. Fireworks events have been concentrated within special periods during specific times of year, such as New Year's Eve (worldwide), the Diwali festival (November, India), Las Fallas (March, Spain), and Lantern Festival (February, China).
The predominance of metal species in airborne particles during the burning of fireworks depends on their chemical fractions. In other words, fireworks contain various chemicals, such as potassium nitrate, potassium chlorate, potassium perchlorate, charcoal, sulfur, manganese, sodium oxalate, aluminum and iron dust powder, strontium nitrate, and barium nitrate, for their own purposes [7]. Potassium salts such as nitrate, chlorate, and perchlorate are widely used as oxidizers in fireworks. $\mathrm{Al}$ and $\mathrm{Mg}$ are widely used as metallic fuels in pyrotechnics, and $\mathrm{Al}$ is also used to give silvery or "flitter" type effects. For coloring effects, $\mathrm{Sr}, \mathrm{Na}, \mathrm{Cu}, \mathrm{Ba}$, and $\mathrm{Ca}$ are used to exhibit red, yellow, blue, green, and orange, respectively [8]. $\mathrm{Pb}$ can be used for achieving a steady and reproducible burning rate [9]. Despite their toxicity, a limited number of studies on metal emissions from fireworks have been reported in the literature $[10,11]$. The annual emissions of $\mathrm{Al}, \mathrm{Mg}, \mathrm{Na}, \mathrm{Ba}, \mathrm{Sr}, \mathrm{Ti}$, and $\mathrm{Cu}$ released from fireworks and other explosives in the UK during 2002 were estimated to be 86,73 (7.6\% of total UK emissions), 5.5 (0.5\%), 65, 10, 5, and 3 (6\%) tons, respectively [10]. In Passant [10], the contribution 
of metal emissions from fireworks and other explosives to their total emissions in the UK was available only for $\mathrm{Mg}, \mathrm{Na}$, and $\mathrm{Cu}$.

One of the interesting episodic (and periodic) sources of trace metals in the atmosphere of Korea is the "Busan Fireworks Festival (BFF)," which takes place every October. The BFF is one of the most significant fireworks festivals in Asia. During the BFF, tens of thousands of fireworks and state-of-the-art lasers light up the sky in harmony with the theme song of the festival against a backdrop of the sea and a 2-level suspension bridge, Gwangan Bridge, drawing crowds of over 1 million visitors each year. The objective of this study was to investigate the impact of fireworks on the short-term spatiotemporal variation of trace metals in PM during three BFF events. The characteristics of trace metals and elements making up the PM after firework burning were investigated using the atmospheric measurements and a high-resolution meteorological model simulation. This study also provides the first attempt to assess the emission rates of various trace metals from the burning of fireworks.

\section{Materials and Methods}

2.1. Site and Measurements. Field measurements at three coastal sites (A1-A3) in Busan, Republic of Korea, were performed during Oct. 2011-2013 to assess the impact of fireworks released from Gwangan Bridge (or Diamond Bridge, $\mathrm{DB}$ ) on the spatiotemporal distribution of trace metals in PM (total suspended particle, TSP) (Figure 1). Sampling site A1, an air quality monitoring site operated by Busan Metropolitan City Institute of Health \& Environment (BMCIHE), is located $2.0 \mathrm{~km}$ west of the bridge (DB); site A2 is located in a regional office of Busan Environmental Corporation, $1.1 \mathrm{~km}$ south of the DB; and site A3 is located at Busan Yachting Center, $0.6 \mathrm{~km}$ east of the DB. The fireworks during the BFF events were set off over the bridge and from barges simultaneously, starting exactly at 20:00 LST (local standard time), for one hour.

PM samples were collected on a Whatman QM-A quartz microfiber filter $(8 \times 10$ inches $)$ using a high volume air sampler (SIBATA HV-1000F, Japan) operating at a flow rate of 1000 L min ${ }^{-1}$. Twenty-four-hour (11:00 am to 11:00 am) integrated samples were obtained during three consecutive days, Oct. 28-30, 2011, Oct. 27-29, 2012, and Oct. 25-27, 2013, for the three BFF events, respectively. The dates of the firework events during 2011-2013 were Oct. 29, 28, and 26 , respectively. One-fourth of each filter was extracted in $30 \mathrm{~mL}$ of $1.03 \mathrm{M} \mathrm{HNO}_{3}+2.23 \mathrm{M} \mathrm{HCl}$ mixture by keeping it in an ultrasonic bath for $2 \mathrm{hr}$ at $100^{\circ} \mathrm{C}$. Metallic compounds and elements in the filtrates were measured by inductively coupled plasma Optical Emission Spectroscopy (Varian ICPOES 720-ES). Five analytes ( $\mathrm{Pb}, \mathrm{Cd}, \mathrm{Cr}, \mathrm{Cu}$, and $\mathrm{As})$ were measured during the $2011 \mathrm{BFF}$ event, and ten analytes $(\mathrm{Pb}$, $\mathrm{Cd}, \mathrm{Cr}, \mathrm{Cu}, \mathrm{As}, \mathrm{Al}, \mathrm{Ca}, \mathrm{Na}, \mathrm{K}$, and $\mathrm{Sr}$ ) were examined during the 2012 and 2013 events.

To examine the impact of fireworks on air quality (especially, $\mathrm{PM}_{10}$ (particles with diameter of 10 micrometers or less) concentration) in Busan, distributions of $\mathrm{PM}_{10}$ were investigated during the daytime (07:00-18:00 LST) and
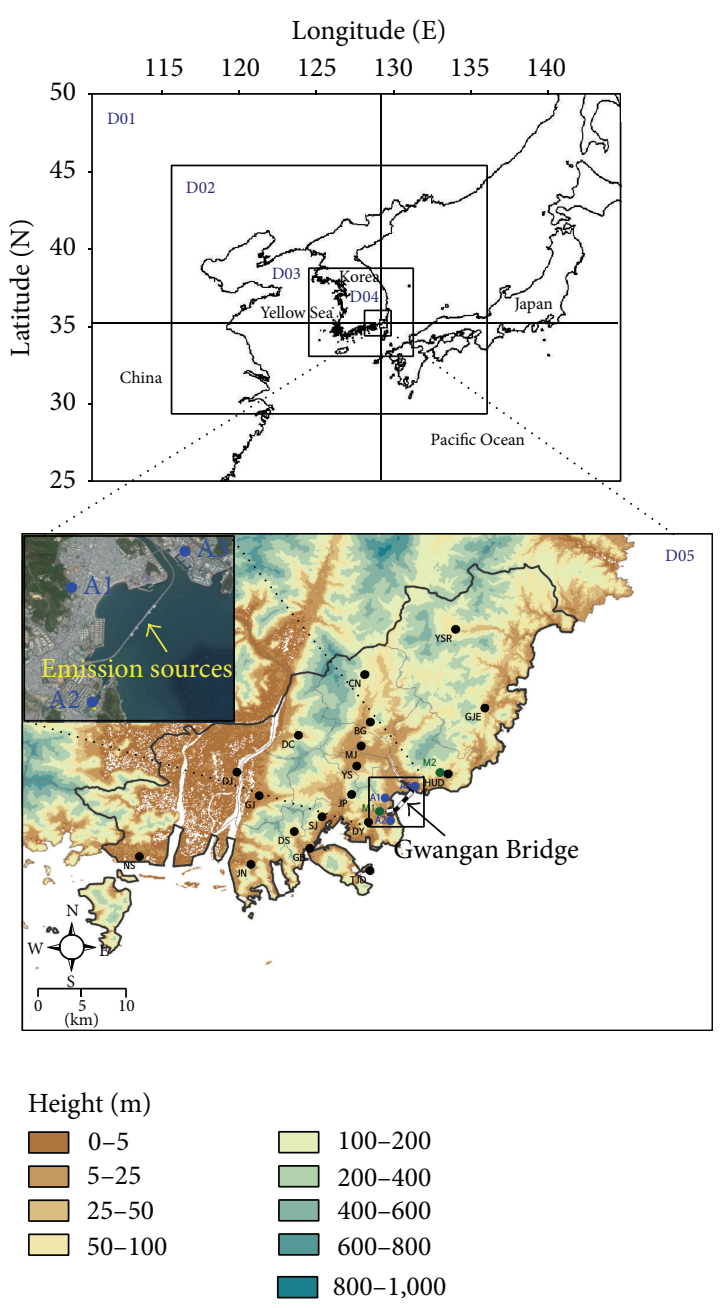

FIGURE 1: Location map of sampling sites (A1-A3) of trace metals and elements during the firework event days of 2011-2013 and meteorological monitoring sites (M1 and M2). Solid black circles represent environmental monitoring sites, where the concentrations of criteria air pollutants $\left(\mathrm{O}_{3}, \mathrm{PM}_{10}, \mathrm{NO}_{2}, \mathrm{CO}\right.$, etc.) are routinely measured.

nighttime (19:00-06:00 LST) for the 2012 and 2013 BFF events due to wide spatial and temporal coverage of $\mathrm{PM}_{10}$ observations instead of trace metals. These analyses were carried out based on hourly concentrations of $\mathrm{PM}_{10}$ observed at eighteen (for 2012) and nineteen (for 2013) environmental monitoring sites in Busan, operated by the Korean Ministry of Environment (Figure 1). In order to deduce the dispersion of trace metals released from the BFF events, the observations of meteorological variables (e.g., temp., RH, wind speed, wind direction, and rainfall) obtained at two meteorological monitoring sites (M1 and M2) close to the environmental monitoring sites (Figure 1) and numerical simulation of wind fields were used in this study.

2.2. Estimation of Trace Metal Emissions in PM. The emissions of trace metals and elements in PM were estimated using their emission factors and the amounts of firework consumed. The data of firework consumption was obtained from 
the Organizing Committee for Busan Culture and Tourism Festival (http://festival.busan.kr/KOR/index.asp). Detailed information on the fireworks used during the BFF events of 2012-2013 is presented in Supplementary Table 1 in the Supplementary Material available online at http://dx.doi.org/ $10.1155 / 2015 / 423275$ and discussed in Section 3.4. The emission factors of trace metals and elements in PM were adopted from the study of Croteau et al. 2010. Croteau et al. 2010 reported the emission factors of trace metals and elements for various types of fireworks, including Dragon Eggs, Ribbon Fuses, Roman Candles, and Fountains (4 types). In this study, the emission factors of aerial shell types of fireworks were set to the average value of the above four types due to lack of data. The emission factor of fountain fireworks was set to the average value of those of four fountain types. The emission factor of cakes was set to the average value of Roman Candles and Dragon Eggs due to the similarity of the fireworks type. The emission factors of other fireworks such as mine, comet, frame, strobe, row, igniter, and delay chain were also set to the average value of the above four types. The emission factors of Co, As, and Cd were adopted from Passant [10].

2.3. Meteorological Model Description. In order to analyze the air mass pathway of metal-rich particles after the burning of fireworks during the BFF events, the meteorological model Weather Research and Forecasting (WRF) version 3.6, which includes fully compressible nonhydrostatic equations, was employed [12]. The model domain was divided into five domains using the two-way nesting method (Supplementary Table 2). The finest domain for the Busan region consisted of 42 sigma vertical levels and $121 \times 121$ grid cells, with a horizontal mesh width of $0.5 \mathrm{~km}$ covering about $34.91^{\circ}-$ $35.42^{\circ} \mathrm{N}$ and $128.74^{\circ}-129.45^{\circ} \mathrm{E}$. Detailed descriptions of the grid information and physical options used for the simulation are given in Supplementary Table 2. The initial/lateral boundary conditions were generated by interpolating the National Center for Environmental Prediction (NCEP) Final Analysis (FNL) fields and the sea surface temperature (SST) data. Moreover, the Objective Analysis technique (OBSGRID) was used to improve the first-guess gridded analysis through incorporation of high-resolution (in time and space) surfaceand upper-level observations. The surface boundary conditions were extracted using the Environmental Geographic Information System (EGIS: a $90 \mathrm{~m}$ resolution) land cover and the Shuttle Radar Topography Mission (SRTM: $90 \mathrm{~m}$ ) topography data sets. To simulate the flow structure and wind fields for the 2012 and 2013 BFF events, the WRF simulations were conducted for a period of $144 \mathrm{hr}$ per event (from 00 UTC on the 24th to 00 UTC on the 30th of October 2012 and from 00 UTC on the 22nd to 00 UTC on the 28th of October 2013, resp.), including a spin-up time. Meanwhile, since the spatial coverage of trace metal observations is restricted to three sites only, $\mathrm{PM}_{10}$ as a proxy for trace metals was used to identify indirectly the air mass pathway in atmospheric dispersion of trace metals after the burning of fireworks, combined with the WRF model results (wind field simulation).

\section{Results and Discussion}

3.1. 2011 BFF Event (Oct. 29, 2011). In 2011, the average concentrations of five trace metals, $\mathrm{Pb}, \mathrm{Cd}, \mathrm{Cr}, \mathrm{Cu}$, and $\mathrm{As}$, on the day of the BFF event (Oct. 29) were found to be $20.8 \pm 5.5$, $0.5 \pm 0.1,3.2 \pm 1.4,15.3 \pm 6.9$, and $6.8 \pm 0.7 \mathrm{ng} \mathrm{m}^{-3}$, respectively (Table 1 and Figure 2). The trace metal masses were in the order $\mathrm{Pb}>\mathrm{Cu}>\mathrm{As}>\mathrm{Cr}>\mathrm{Cd}$. None of the concentrations were higher than those during the previous day, excluding As, which was a factor of 1.3-1.8 higher except at the A1 site. The As concentration $\left(6.5 \mathrm{ng} \mathrm{m}^{-3}\right)$ at the A1 site on the BFF day was similar to that $\left(6.1 \mathrm{ng} \mathrm{m}^{-3}\right)$ during the previous day. On the next day (Oct. 30), the characteristics of the five trace metals remained the same as the event day. However, the As concentrations $\left(9.8-10.6 \mathrm{ng} \mathrm{m}^{-3}\right)$ at all three sites were a factor of 1.5 (A1)-2.9 (A2) higher than those during the day before the event day (Oct. 28). The trace metal concentrations on Oct. 29-30 were very similar, except for As. The insignificant differences in the trace metal concentrations during these two days were likely to be related to washout effects of the trace metals on the BFF day due to rainfall $(9.3 \mathrm{~mm})$.

Predominance of $\mathrm{Pb}$ and $\mathrm{Cu}$ in trace metal distribution during the pre-BFF day was the same as that after the burning of fireworks (Oct. 29-30), implying no significant contribution of fireworks burning to their total emissions in this event. In contrast, the ratios of As to $\mathrm{Cr}(2.1-3.9)$ after the burning of fireworks were significantly higher than that (1.2) during the pre-BFF day, implying significant contribution of fireworks burning to As levels. Note that an annual median (mean) ratio of As to Cr for TSP in Busan in 2011 was 0.8 (0.5) [13]. Annual mean concentration of As in 2011 was $6.2 \pm 1.7 \mathrm{ng} \mathrm{m}^{-3}$. Significant enhancement of As concentration during postfireworks was also observed in Taiwan [14]. Note that the concentrations of trace metals during the event day might be significantly reduced due to rainfall. Meanwhile, firework metals during the study period of 2011 exhibited significant positive correlation $(r=0.67 \sim 0.91)$, except for As (negative correlation, $r=-0.46 \sim-0.67$ ), pointing their common source (fireworks) (not shown).

The meteorological conditions during the three days, observed at two Automatic Weather Stations (AWS) operated by Korea Meteorological Administration (KMA) near the sampling sites, are presented in Table 1. Mean daytime temperature and relative humidity were $17.3-19.3^{\circ} \mathrm{C}$ and $56.1-$ $73.8 \%$, respectively. The main wind direction and mean wind speed during the daytime of the event day were $\mathrm{NE}$ (and NW) and $2.4 \mathrm{~m} \mathrm{~s}^{-1}$, respectively. The mean temperature during the nighttime was $1.5-3.2^{\circ} \mathrm{C}$ lower than the daytime, while relative humidity was $9.3 \%$ higher. Wind speeds during the nighttime were $1.6-2.4 \mathrm{~m} \mathrm{~s}^{-1}$, showing no distinct difference between day and night. The higher mean concentration at the A3 site can be ascribed in part to the air mass pathway (NE and NW), which may have carried the firework air mass to the sampling site.

Out of the three aerosol sampling sites, the $\mathrm{PM}_{10}$ concentration data during the day of the BFF event were available only at site Al. The $\mathrm{PM}_{10}$ concentrations at the Al site $\left(19.6 \mu \mathrm{g} \mathrm{m}^{-3}\right)$ during the nighttime of the event day were 
TABLE 1: Statistical summary (mean \pm standard deviation) of meteorological parameters at two sites M1-M2 during the daytime (a) and nighttime (b) and daily mean concentrations of trace metal and elements at three sites A1-A3 (c) during the study periods.

(a) Daytime

\begin{tabular}{lccccccccc}
\hline Parameters & & 2011 & & & 2012 & & \multicolumn{2}{c}{2013} \\
& Oct. 28 & Oct. 29 & Oct. 30 & Oct. 27 & Oct. 28 & Oct. 29 & Oct. 25 & Oct. 26 & Oct. 27 \\
\hline Temp. $\left({ }^{\circ} \mathrm{C}\right)$ & $19.1 \pm 2.4$ & $19.3 \pm 1.1$ & $17.3 \pm 0.7$ & $17.4 \pm 1.1$ & $19.9 \pm 2.2$ & $17.6 \pm 3.0$ & $17.6 \pm 2.0$ & $16.4 \pm 2.3$ & $16.3 \pm 2.9$ \\
$\mathrm{RH}(\%)$ & 56.1 & 66.4 & 73.8 & 91.5 & 46.3 & 57.8 & 48.7 & 51.3 & 46.3 \\
Wind speed $\left(\mathrm{m} \mathrm{s}^{-1}\right)$ & $2.0 \pm 0.7$ & $2.4 \pm 0.9$ & $2.2 \pm 0.8$ & $1.7 \pm 1.3$ & $3.1 \pm 1.1$ & $1.3 \pm 0.7$ & $2.5 \pm 0.8$ & $1.7 \pm 0.6$ & $2.4 \pm 1.2$ \\
Wind direction & $\mathrm{NE} / \mathrm{NW}$ & $\mathrm{NE} / \mathrm{NW}$ & $\mathrm{NE}$ & $\mathrm{NE}$ & $\mathrm{NW} / \mathrm{SW}$ & $\mathrm{SW} / \mathrm{SE}$ & $\mathrm{NE}$ & $\mathrm{NW} / \mathrm{NE}$ & $\mathrm{SW}$ \\
$\mathrm{Rainfall}(\mathrm{mm})^{0}$ & 0 & 0 & 97 & 0 & 0 & 0 & 0 & 0 \\
$\mathrm{PM}_{10}\left(\mu \mathrm{g} \mathrm{m}^{-3}\right)^{*}$ & $19.9 \pm 6.3$ & $22.9 \pm 6.7$ & $13.1 \pm 4.8$ & $24.4 \pm 7.6$ & $27.2 \pm 8.8$ & $34.9 \pm 4.6$ & $49.2 \pm 6.4$ & $34.6 \pm 5.4$ & $40.3 \pm 7.2$ \\
$\mathrm{O}_{3}(\mathrm{ppb})^{*}$ & - & $33 \pm 5$ & $35 \pm 2$ & $27 \pm 8$ & $48 \pm 3$ & $34 \pm 18$ & $41 \pm 12$ & $36 \pm 7$ & $45 \pm 12$ \\
\hline
\end{tabular}

${ }^{*}$ Concentrations at the $\mathrm{Al}$ site.

(b) Nighttime

\begin{tabular}{lccccccccc}
\hline Parameters & \multicolumn{3}{c}{2011} & & \multicolumn{2}{c}{2012} & & \multicolumn{2}{c}{2013} \\
& Oct. 28 & Oct. 29 & Oct. 30 & Oct. 27 & Oct. 28 & Oct. 29 & Oct. 25 & Oct. 26 & Oct. 27 \\
\hline Temp. $\left({ }^{\circ} \mathrm{C}\right)$ & $17.6 \pm 0.8$ & $\mathbf{1 6 . 1} \pm \mathbf{0 . 5}$ & $15.1 \pm 0.7$ & $18.6 \pm 0.8$ & $\mathbf{1 4 . 4} \pm \mathbf{2 . 2}$ & $15.1 \pm 1.2$ & $12.7 \pm 1.6$ & $\mathbf{1 2 . 1} \pm \mathbf{2 . 2}$ & $11.3 \pm 2.0$ \\
$\mathrm{RH}(\%)$ & 68.2 & $\mathbf{8 4 . 6}$ & 71.4 & 83.5 & $\mathbf{5 5 . 1}$ & 65.9 & 61.3 & $\mathbf{6 6 . 8}$ & 63.2 \\
Wind speed $\left(\mathrm{m} \mathrm{s}^{-1}\right)$ & $1.6 \pm 0.7$ & $\mathbf{2 . 4} \pm \mathbf{0 . 9}$ & $2.4 \pm 0.6$ & $2.3 \pm 0.9$ & $\mathbf{1 . 0} \pm \mathbf{0 . 6}$ & $1.3 \pm 0.9$ & $1.6 \pm 0.5$ & $\mathbf{0 . 9} \pm \mathbf{0 . 5}$ & $0.3 \pm 0.3$ \\
Wind direction & $\mathrm{NE} / \mathrm{NW}$ & $\mathbf{N E}$ & $\mathrm{NE} / \mathrm{NW}$ & $\mathrm{SW}$ & $\mathrm{NW} / \mathrm{SW}$ & $\mathrm{NW}$ & $\mathrm{NW}$ & $\mathrm{NW} / \mathrm{SW}$ & $\mathrm{NE}$ \\
Rainfall $(\mathrm{mm})$ & 0 & $\mathbf{9 . 3}$ & 0 & 38 & $\mathbf{0}$ & 0 & 0 & $\mathbf{0}$ & 0 \\
$\mathrm{PM}_{10}\left(\mu \mathrm{g} \mathrm{m}^{-3}\right)^{*}$ & $18.6 \pm 2.5$ & $\mathbf{1 9 . 6} \pm \mathbf{7 . 6}$ & $22.9 \pm 3.9$ & $19.1 \pm 7.7$ & $\mathbf{3 2 . 5} \pm \mathbf{5 . 0}$ & $31.0 \pm 5.2$ & $42.8 \pm 3.4$ & $\mathbf{3 5 . 2} \pm \mathbf{5 . 5}$ & $34.5 \pm 2.9$ \\
$\mathrm{O}_{3}(\mathrm{ppb})^{*}$ & $37 \pm 3$ & $\mathbf{3 4} \pm \mathbf{5}$ & $31 \pm 2$ & $34 \pm 4$ & $\mathbf{3 0} \pm \mathbf{6}$ & $35 \pm 5$ & $25 \pm 8$ & $\mathbf{3 2} \pm \mathbf{8}$ & $34 \pm 10$ \\
\hline
\end{tabular}

${ }^{*}$ Concentrations at the $\mathrm{A} 1$ site.

(c) All day

\begin{tabular}{lccccccccc}
\hline \multirow{2}{*}{ Metal and elements } & \multicolumn{3}{c}{2011} & & 2012 & & \multicolumn{2}{c}{2013} \\
& Oct. 28 & Oct. 29 & Oct. 30 & Oct. 27 & Oct. 28 & Oct. 29 & Oct. 25 & Oct. 26 & Oct. 27 \\
\hline $\mathrm{Pb}\left(\mathrm{ng} \mathrm{m}^{-3}\right)$ & $31.9 \pm 2.0$ & $\mathbf{2 0 . 8} \pm \mathbf{5 . 5}$ & $20.7 \pm 0.7$ & $15.0 \pm 2.6$ & $\mathbf{4 3 . 7} \pm \mathbf{7 . 6}$ & $34.3 \pm 14.5$ & $30.3 \pm 11.0$ & $\mathbf{3 7 . 3} \pm \mathbf{1 1 . 7}$ & $30.7 \pm 5.7$ \\
$\mathrm{Cd}\left(\mathrm{ng} \mathrm{m}^{-3}\right)$ & $0.8 \pm 0.2$ & $\mathbf{0 . 5} \pm \mathbf{0 . 1}$ & $0.4 \pm 0.1$ & $<0.1$ & $\mathbf{1 . 0} \pm \mathbf{0 . 0}$ & $0.67 \pm 0.58$ & $<0.1$ & $<\mathbf{0 . 1}$ & $<0.1$ \\
$\mathrm{Cr}\left(\mathrm{ng} \mathrm{m}^{-3}\right)$ & $4.4 \pm 2.0$ & $\mathbf{3 . 2} \pm \mathbf{1 . 4}$ & $2.6 \pm 0.6$ & $9.7 \pm 0.6$ & $\mathbf{1 2 . 7} \pm \mathbf{0 . 6}$ & $12.7 \pm 2.5$ & $1.7 \pm 1.5$ & $\mathbf{2 . 7} \pm \mathbf{1 . 5}$ & $1.3 \pm 2.3$ \\
$\mathrm{Cu}\left(\mathrm{ng} \mathrm{m}^{-3}\right)$ & $27.5 \pm 9.5$ & $\mathbf{1 5 . 3} \pm \mathbf{6 . 9}$ & $15.6 \pm 8.7$ & $10.3 \pm 3.1$ & $\mathbf{2 7 . 7} \pm \mathbf{1 0 . 3}$ & $21.7 \pm 13.3$ & $15.3 \pm 4.0$ & $\mathbf{2 5 . 7} \pm \mathbf{1 1 . 0}$ & $29.3 \pm 19.7$ \\
$\mathrm{As}\left(\mathrm{ng} \mathrm{m}^{-3}\right)$ & $5.4 \pm 1.5$ & $\mathbf{6 . 8} \pm \mathbf{0 . 7}$ & $10.1 \pm 0.4$ & $<0.1$ & $\mathbf{1 . 0} \pm \mathbf{1 . 0}$ & $6.3 \pm 7.6$ & $6.0 \pm 3.0$ & $\mathbf{3 . 0} \pm \mathbf{5 . 2}$ & $1.0 \pm 1.7$ \\
$\mathrm{Sr}\left(\mathrm{ng} \mathrm{m}^{-3}\right)$ & & & & $3.0 \pm 1.7$ & $\mathbf{5 . 7} \pm \mathbf{1 . 5}$ & $3.7 \pm 1.2$ & $5.3 \pm 0.6$ & $\mathbf{1 4 . 3} \pm \mathbf{1 9 . 6}$ & $3.0 \pm 1.0$ \\
$\mathrm{Al}\left(\mu \mathrm{g} \mathrm{m}^{-3}\right)$ & & & & $0.06 \pm 0.01$ & $\mathbf{0 . 3 2} \pm \mathbf{0 . 0 9}$ & $0.21 \pm 0.07$ & $0.54 \pm 0.03$ & $\mathbf{0 . 4 7} \pm \mathbf{0 . 0 6}$ & $0.34 \pm 0.04$ \\
$\mathrm{~K}\left(\mu \mathrm{g} \mathrm{m}^{-3}\right)$ & & & & $0.32 \pm 0.03$ & $\mathbf{0 . 4 2} \pm \mathbf{0 . 0 2}$ & $0.31 \pm 0.08$ & $0.29 \pm 0.03$ & $\mathbf{0 . 5 2} \pm \mathbf{0 . 3 9}$ & $0.22 \pm 0.17$ \\
$\mathrm{Na}\left(\mu \mathrm{g} \mathrm{m}^{-3}\right)$ & & & & $4.3 \pm 2.6$ & $\mathbf{2 . 3} \pm \mathbf{0 . 2}$ & $2.7 \pm 0.5$ & $0.80 \pm 0.32$ & $\mathbf{0 . 7 0} \pm \mathbf{0 . 3 6}$ & $0.35 \pm 0.29$ \\
$\mathrm{Ca}\left(\mu \mathrm{g} \mathrm{m}^{-3}\right)$ & & & & $0.28 \pm 0.07$ & $\mathbf{1 . 0} \pm \mathbf{0 . 3}$ & $0.68 \pm 0.20$ & $1.10 \pm 0.08$ & $\mathbf{0 . 8 5} \pm \mathbf{0 . 1 2}$ & $0.73 \pm 0.08$ \\
\hline
\end{tabular}

lower than those $\left(22.9 \mu \mathrm{g} \mathrm{m}^{-3}\right)$ during the daytime. The $\mathrm{PM}_{10}$ concentrations during the daytime on the next day $\left(13.1 \mu \mathrm{g} \mathrm{m}^{-3}\right)$ dropped by $30 \%$. This was likely due mainly to the influence of moderate rainfall during the nighttime of the event day. In contrast, the $\mathrm{O}_{3}$ concentrations (34 ppb) during the nighttime of the event day were similar to those (33 ppb) during the daytime, indicating different sources/destruction mechanisms between these two air pollutants. In general, nighttime $\mathrm{O}_{3}$ concentration is lower than daytime $\mathrm{O}_{3}$ concentration due to nighttime titration by $\mathrm{NO}$.

3.2. 2012 BFF Event (Oct. 28, 2012). In 2012, the average concentrations of six trace metals $\mathrm{Pb}, \mathrm{Cd}, \mathrm{Cr}, \mathrm{Cu}, \mathrm{As}$, and $\mathrm{Sr}$ on the BFF event day (Oct. 28) were found to be $44 \pm 8,1.0$,
$13 \pm 1,28 \pm 10,1.0 \pm 1.0$, and $5.7 \pm 1.5 \mathrm{ng} \mathrm{m}^{-3}$, respectively (Table 1 and Figure 3). In 2012, the distributions of trace metal concentrations were somewhat different from those in 2011. For instance, the trace metal masses were in the order $\mathrm{Pb}>$ $\mathrm{Cu}>\mathrm{Cr}>\mathrm{Sr}>\mathrm{As}, \mathrm{Cd}$. The As concentration $\left(1.0 \mathrm{ng} \mathrm{m}^{-3}\right)$ was significantly lower compared to that during the 2011 event $\left(6.8 \mathrm{ng} \mathrm{m}^{-3}\right)$. In contrast to the 2011 event, all concentrations during the event day were higher than those during the previous day. The most significant enhancement of trace metal concentration was observed for $\mathrm{Pb}\left(44 \mathrm{ng} \mathrm{m}^{-3}\right)$, which was a factor of 2.91 higher than the concentration $\left(15 \mathrm{ng} \mathrm{m}^{-3}\right)$ during the previous day (Oct. 27). Strong enhancement of $\mathrm{Pb}$ (oxidizer) level (7 times) after firework burning was also reported in Spain [15]. Significant enhancement (2.7 times) of 


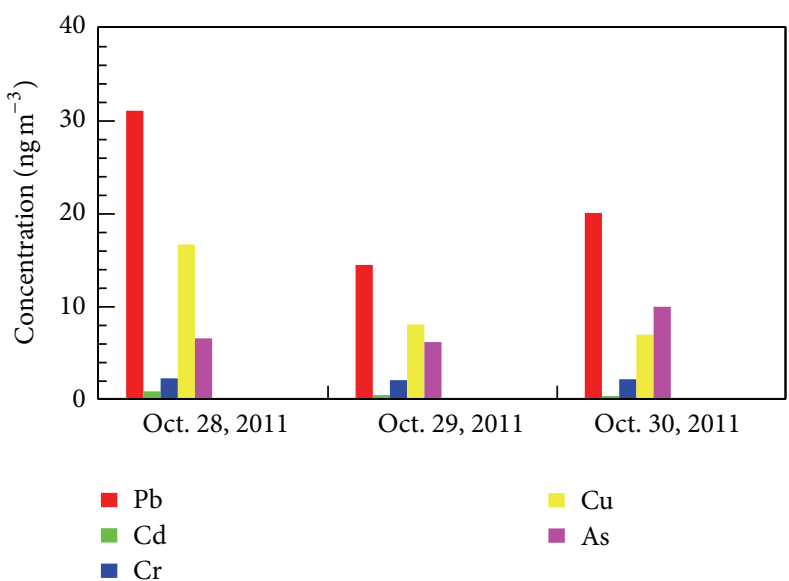

(a) $\mathrm{A} 1$

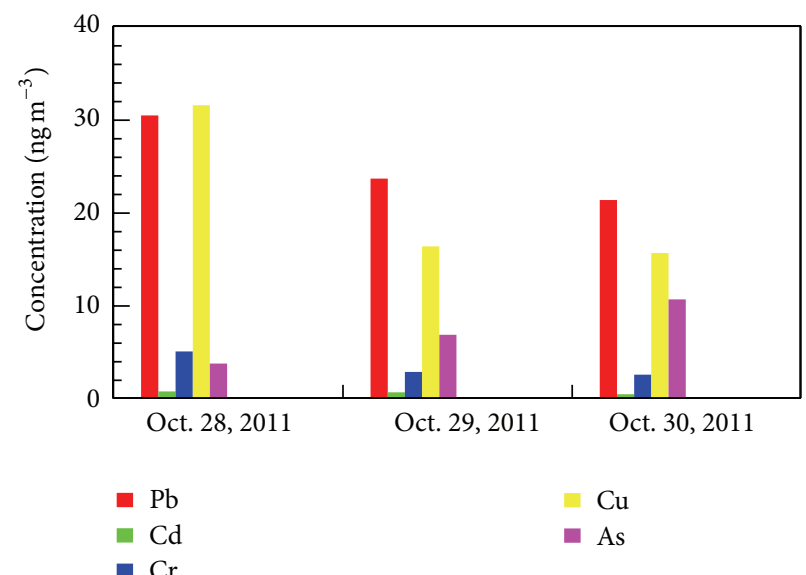

(b) A2

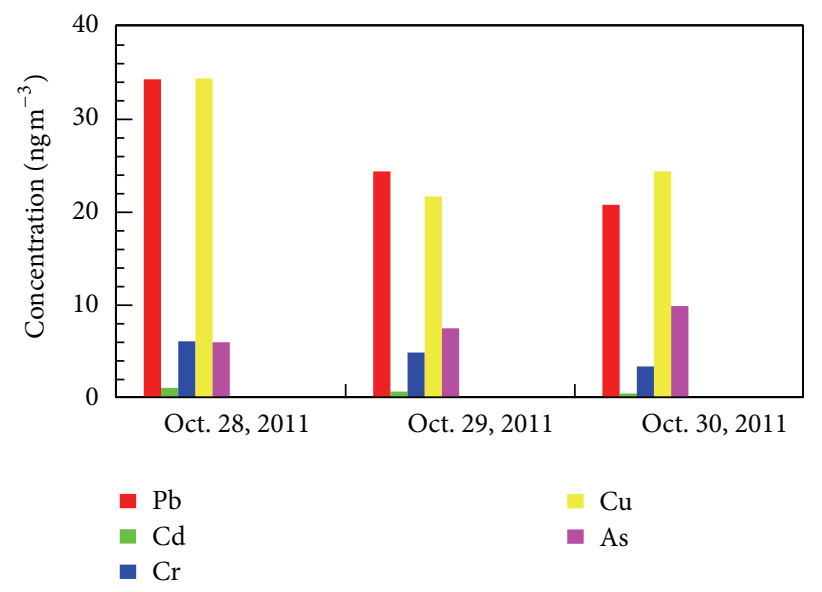

(c) A3

FIGURE 2: Concentrations of metals during the Busan Fireworks Festival event (Oct. 29) in 2011, measured at three monitoring sites (A1-A3).

$\mathrm{Cu}$ (as a colorant: blue) concentration during the event day was also observed compared to the pre-BFF day. Unlike 2011 event, the ratio of As to $\mathrm{Cr}$ (0.1) during the BFF event day was significantly lower than the annual mean ratio $(1.6 \pm 1.0)$ in TSP in 2012 [16], implying insignificant contribution of fireworks burning to As levels. Compared to an annual mean concentration of As $\left(11 \pm 16 \mathrm{ng} \mathrm{m}^{-3}\right)$ in 2012, As concentration during the event day was significantly lower, suggesting an insignificant role of fireworks in its ambient level. The ratio dropped to the annual mean ratio next day. In addition, Sr (as a colorant: red) concentration during the event day was somewhat (1.9 times) enhanced, which is one of key tracers (Ba (264 times), K (18 times), and Sr (15 times) of firework burning in Diwali festival [17]). In general, the enhancement of trace metal concentrations during the event day was somewhat weakened (20-43\%) compared to those during the next day (Oct. 29). Compared to the 2011 event, the spatial variation of trace metal concentrations with the sampling sites was generally slightly less, except for As.

The concentrations of the four elements examined were significantly higher than those of the six trace metals, up to three orders of magnitude. For instance, the average concentrations of the elements $\mathrm{Al}, \mathrm{K}, \mathrm{Na}$, and $\mathrm{Ca}$ on the $\mathrm{BFF}$ event day were found to be $0.32 \pm 0.09,0.42 \pm 0.02$, $2.34 \pm 0.22$, and $1.01 \pm 0.33 \mu \mathrm{g} \mathrm{m}^{-3}$, respectively (Table 1 ). The masses of the four elements were in the order $\mathrm{Na}>\mathrm{Ca}$ $>\mathrm{K}>\mathrm{Al}$. The $\mathrm{Na}$ concentrations were a factor of 2.3-7.3 higher than the concentrations of other elements possibly due to sea-salt origin. All concentrations were higher during the event day than during the previous day, except for $\mathrm{Na}$. Concentrations of $\mathrm{K}$ (as the oxidizer and tracer in firework burning) and $\mathrm{Ca}$ (as a colorant: orange) during the event day were a factor of 1.3 and 3.6 higher than those during pre-BFF day, respectively. Of the four elements, $\mathrm{Al}$ (as metallic fuel) concentration $\left(0.32 \mu \mathrm{g} \mathrm{m}^{-3}\right)$ during the BFF day increased significantly by a factor of 5.4 compared to the previous day $\left(0.06 \mu \mathrm{g} \mathrm{m}^{-3}\right)$. During the day after the event day, all concentrations decreased to some extent (26-34\%), except for $\mathrm{Na}(16 \%$ increase possibly due to the influence of marine air masses), compared to the event day. In general, trace metals and elements such as $\mathrm{Cr}, \mathrm{Cu}, \mathrm{Al}, \mathrm{Ca}$, and $\mathrm{Sr}$ during the study period of 2012 exhibited significant correlation between themselves, suggesting their common source (Table 3). The fraction of mineral dust of earth's crust origin in the aerosol 


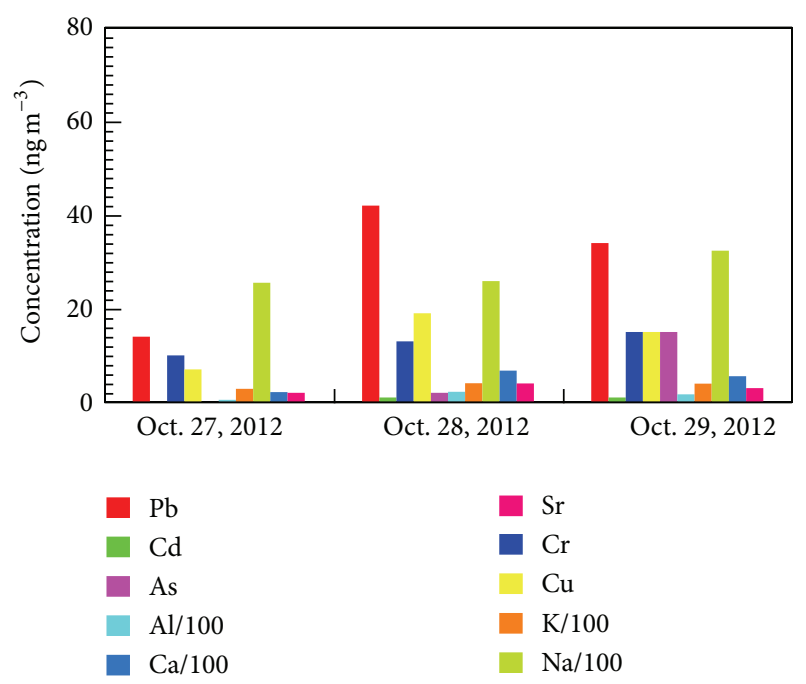

(a) A1

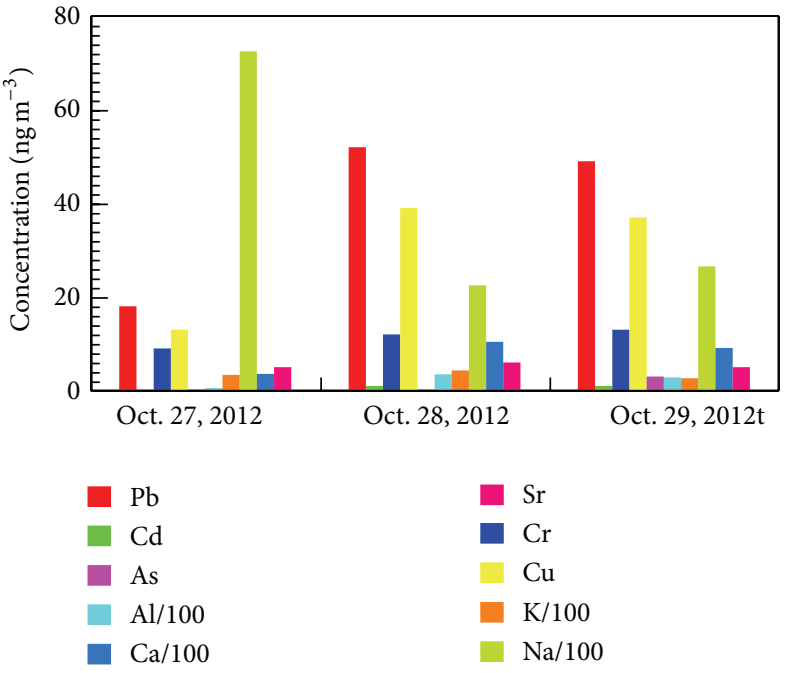

(b) A2

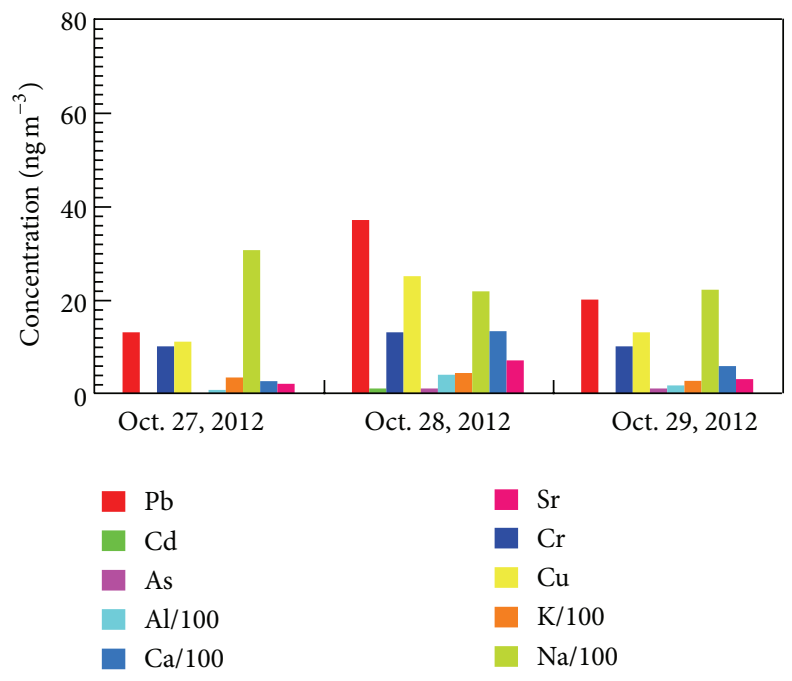

(c) A3

FIGURE 3: Concentrations of metals and elements during the Busan Fireworks Festival event (Oct. 28) in 2012, measured at three monitoring sites (Al-A3). The concentrations of $\mathrm{K}, \mathrm{Ca}, \mathrm{Al}$, and Na were scaled down by a factor of 100 .

samples can be calculated using the $\mathrm{Al}$ concentration ( $8 \%$, [18]). The fractions of mineral dust during the three days (Oct. 27-29) were 2.1, 8.4, and 8.4\% of the total $\mathrm{PM}_{10}$ mass, respectively, indicating an insignificant fraction of mineral dust during the pre-BFF day. The increase of the mineral dust fraction (contamination) after firework burning might be related to the $\mathrm{Al}$ emission from fireworks, as $\mathrm{Al}$ is also used to give the silvery or "flitter" type effect.

The mean daytime temperature and relative humidity were $17.4-19.9^{\circ} \mathrm{C}$ and $46.3-91.5 \%$, respectively. On Oct. 27 , there was significant rainfall $(67.5 \mathrm{~mm})$. The main wind direction and mean wind speed during the night of the event day were NW (and SW) and $1.0 \mathrm{~m} \mathrm{~s}^{-1}$, respectively. The meteorological conditions during the 2012 event were somewhat different from those during the 2011 event. The mean nighttime temperature was $2.4-5.5^{\circ} \mathrm{C}$ lower than that during the daytime, while the relative humidity was 8$9 \%$ higher, except for Oct. 27. Since wind speeds during the nighttime were relatively weak $\left(1.0-2.3 \mathrm{~m} \mathrm{~s}^{-1}\right)$, the trace metals after the burning of fireworks might not be widely dispersed, causing their accumulation.

Unlike the 2011 event, the $\mathrm{PM}_{10}$ concentrations at the A1 site were higher during the nighttime of the event day $\left(32.5 \mu \mathrm{g} \mathrm{m}^{-3}\right)$ than during the daytime $\left(27.2 \mu \mathrm{g} \mathrm{m}^{-3}\right)$. The $\mathrm{PM}_{10}$ concentrations during the daytime of the next day $\left(34.9 \mu \mathrm{g} \mathrm{m}^{-3}\right)$ were similar to those during the nighttime of the event day. The fireworks might have caused up to a $10 \mu \mathrm{g} \mathrm{m}^{-3}$ increase of $\mathrm{PM}_{10}$ (i.e., the difference between during nighttime and during daytime of the event day) at the coastlines and around the inland regions adjacent to Gwangan Bridge (Figure 4). This suggested that fireworks might increase $\mathrm{PM}_{10}$ levels by up to $37 \%$. Similar enhancement 

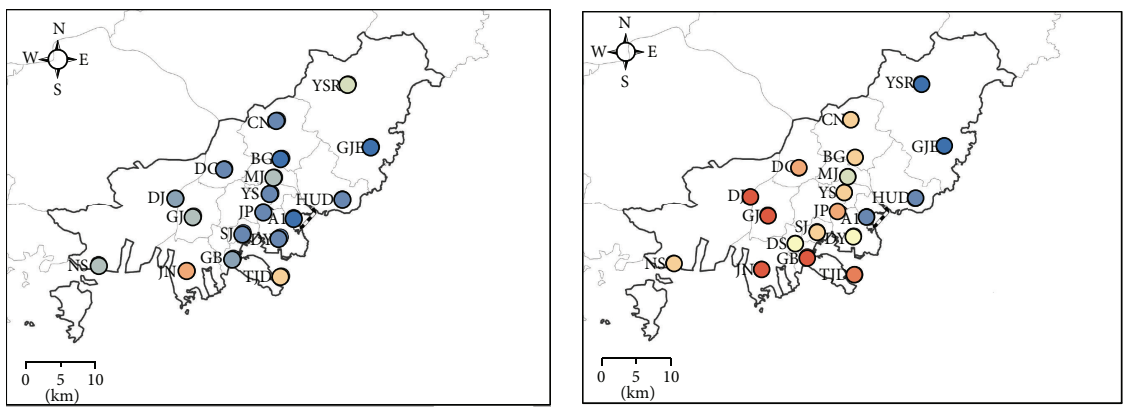

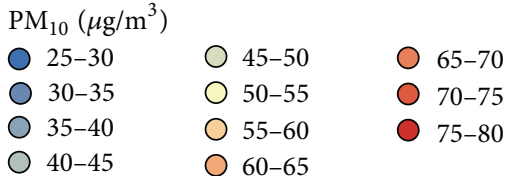

(a) 2012 BFF event-daytime

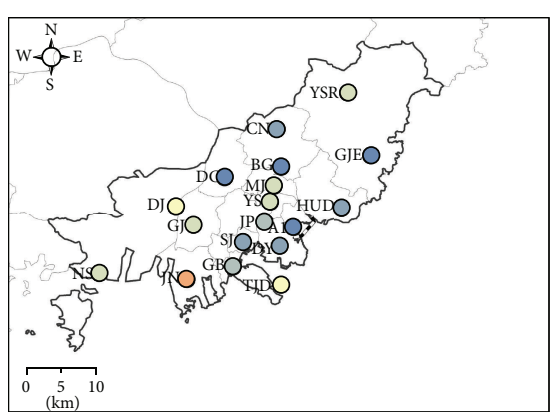

$\mathrm{PM}_{10}\left(\mu \mathrm{g} / \mathrm{m}^{3}\right)$

\begin{tabular}{|c|c|c|}
\hline $25-30$ & ○ $45-50$ & ○ $65-70$ \\
\hline $30-35$ & (50-55 & ○ $70-75$ \\
\hline 35-40 & 55-60 & 75-80 \\
\hline ○ $40-45$ & 60-65 & \\
\hline
\end{tabular}

(d) 2013 BFF event-daytime

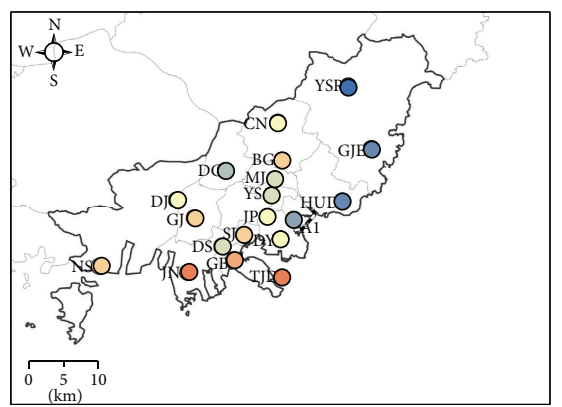

$\mathrm{PM}_{10}\left(\mu \mathrm{g} / \mathrm{m}^{3}\right)$

\begin{tabular}{|c|c|c|}
\hline 25-30 & (45-50 & 65-70 \\
\hline O $30-35$ & ○ 50-55 & $70-75$ \\
\hline 35-40 & 55-60 & 75-80 \\
\hline $40-45$ & $60-65$ & \\
\hline
\end{tabular}

(e) 2013 BFF event—nighttime

(b) 2012 BFF event-nighttime
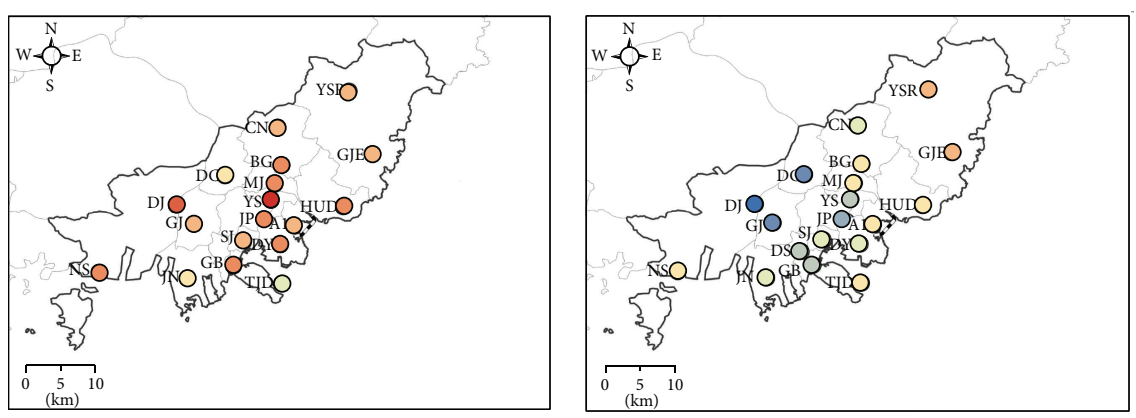

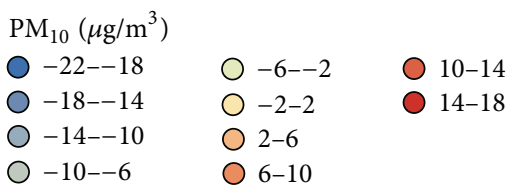

(c) 2012 BFF event-diff. (NT versus DT)

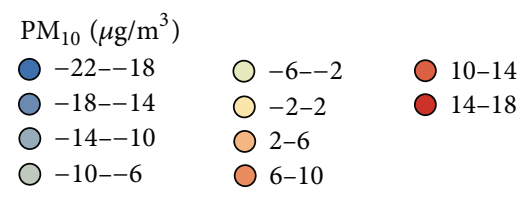

(f) $2013 \mathrm{BFF}$ event-diff. (NT versus DT)

FIGURE 4: Distribution of daytime ((a) and (d)) and nighttime ((b) and (e)) $\mathrm{PM}_{10}$ concentrations and concentration differences between nighttime and daytime ((c) and (f)) during the BFF event days. 


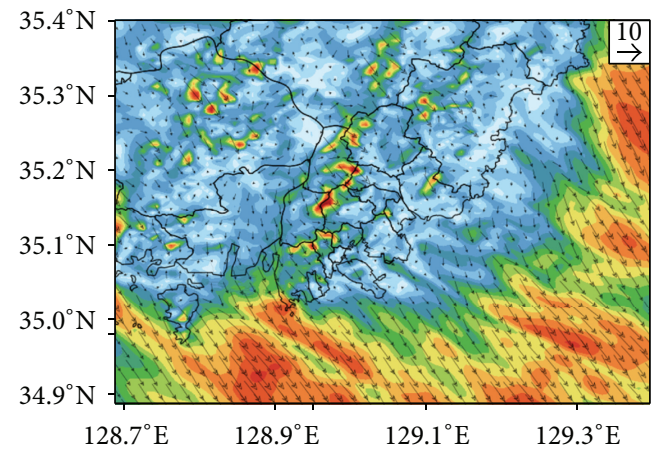

(a) 2100 LST, Oct. 28,2012

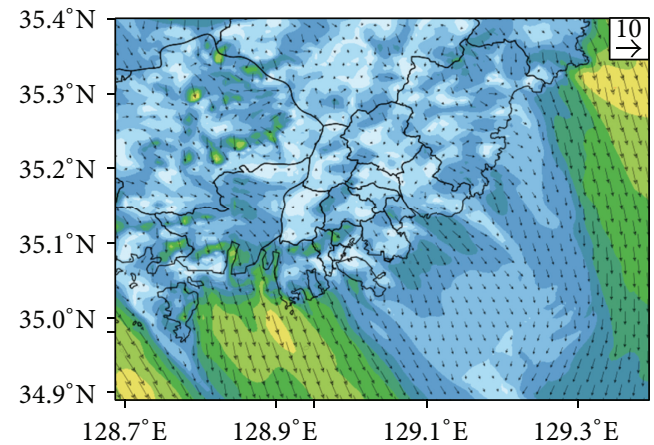

(b) 0300 LST, Oct. 29, 2012

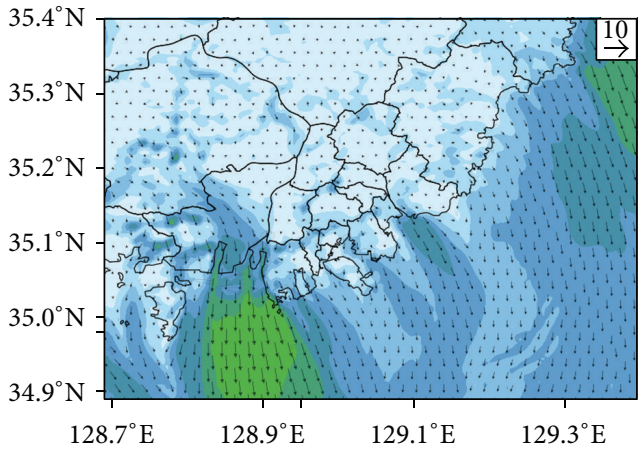

(c) 0900 LST, Oct. 29, 2012
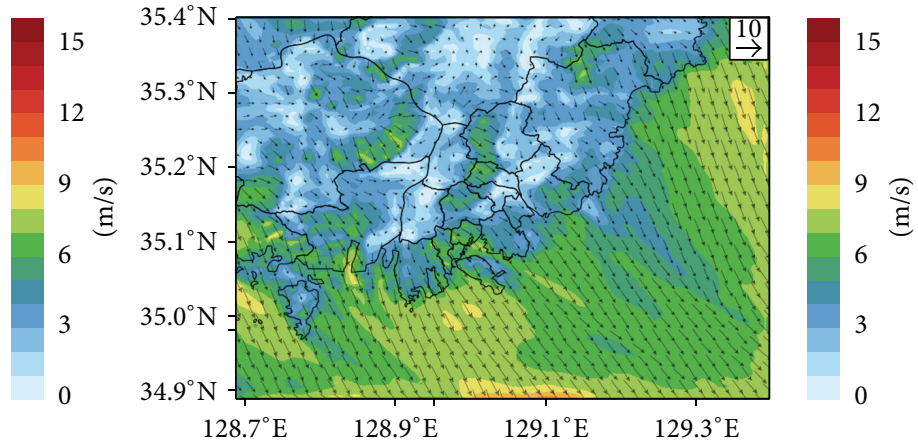

(d) 2100 LST, Oct. 26, 2013
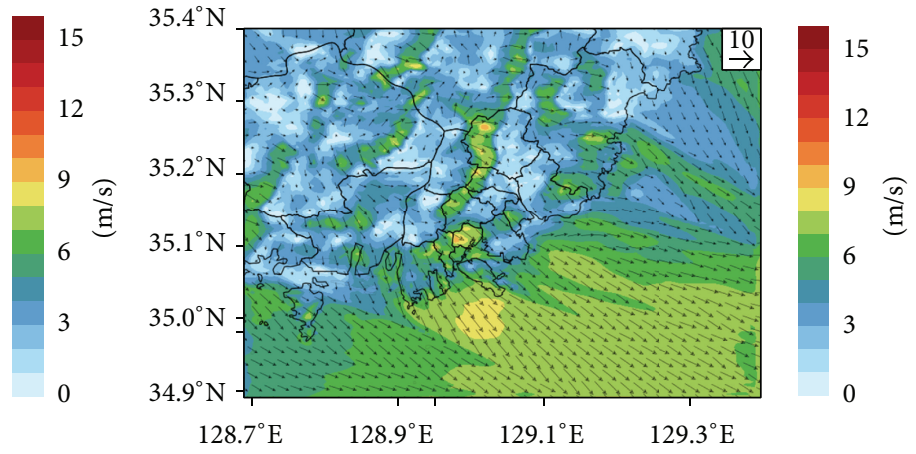

(e) 0300 LST, Oct. 27, 2013

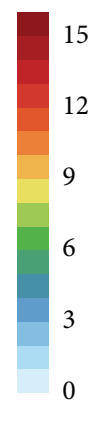

FIGURE 5: Surface wind field at $10 \mathrm{~m}$ AGL distribution simulated by the WRF model in the evening (21:00 LST) of the BFF event day, early morning (03:00 LST), and morning (09:00 LST) of the next day in 2012-2013.

of $\mathrm{PM}_{10}$ levels was also observed during the Diwali festival $[4,17,19]$. Overall, large or moderate increases of $\mathrm{PM}_{10}$ were shown in most of areas (18 sites) during the nighttime of the event day. The main cause of this increase can likely be ascribed to the fireworks, according to the monthly mean $\mathrm{PM}_{10}$ concentrations during the nighttime $\left(40.2 \mu \mathrm{g} \mathrm{m}^{-3}\right)$ and daytime $\left(43.9 \mu \mathrm{g} \mathrm{m}^{-3}\right)$ for Oct. 2012 in Busan. In general, the $\mathrm{PM}_{10}$ concentration during the nighttime was somewhat lower than that of the daytime, except for during the fireworks event. Geographical patterns in the increase of $\mathrm{PM}_{10}$ concentration were distinguished in part due to the effects of meteorological conditions (the northwesterly (NW) and southwesterly (SW) winds) during the nighttime of the event day (Figure 5). Unlike the 2011 event, $\mathrm{O}_{3}$ concentrations during the nighttime of the event day (30 ppb) were lower than those during the daytime ( $48 \mathrm{ppb}$ ). This pattern was also observed during the 2013 event.

3.3. 2013 BFF Event (Oct. 26, 2013). In 2013, the average concentrations of six trace metals $\mathrm{Pb}, \mathrm{Cd}, \mathrm{Cr}, \mathrm{Cu}, \mathrm{As}$, and Sr on the BFF event day were found to be $37 \pm 12,<0.1$, $2.7 \pm 1.5,26 \pm 11,3.0 \pm 5.2$, and $14 \pm 20 \mathrm{ng} \mathrm{m}^{-3}$, respectively (Table 1 and Figure 6). In 2013, the distribution of trace metal concentration was somewhat different from those during the event days of 2011-2012. In this case, the trace metal masses were in the order $\mathrm{Pb}>\mathrm{Cu}>\mathrm{Sr}>\mathrm{As}>\mathrm{Cr}>\mathrm{Cd}$. In addition, the $\mathrm{Sr}$ concentration $\left(14 \mathrm{ng} \mathrm{m}^{-3}\right.$ ) was significantly higher (by a factor of 2.7) compared to the pre-BFF day $\left(5.3 \mathrm{ng} \mathrm{m}^{-3}\right)$, even 


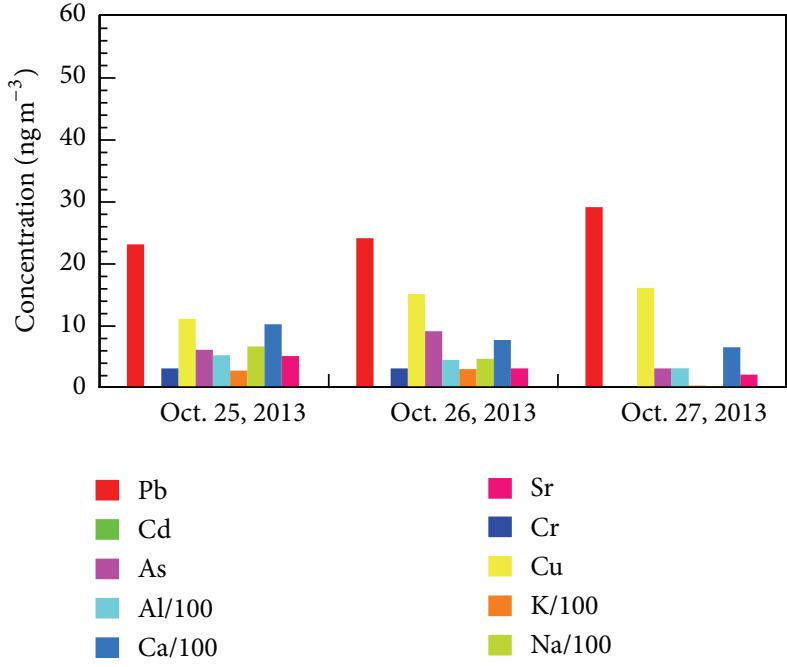

(a) Al

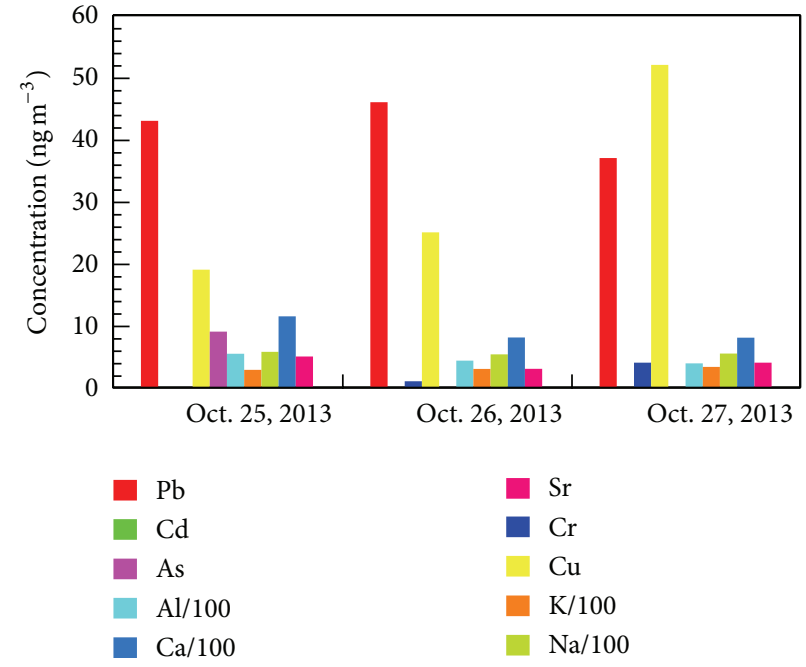

(b) A2

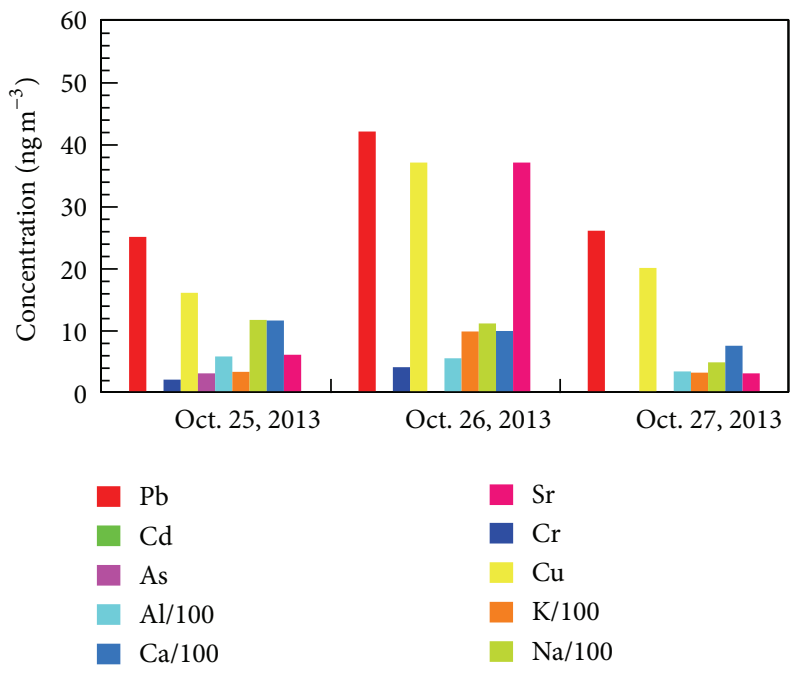

(c) A3

Figure 6: Concentrations of metals and elements during the Busan Fireworks Festival event (Oct. 26) in 2013, measured at three monitoring sites (A1-A3). The concentrations of $\mathrm{K}, \mathrm{Ca}, \mathrm{Al}$, and $\mathrm{Na}$ were scaled down by a factor of 100 .

of the 2012 event $\left(5.7 \mathrm{ng} \mathrm{m}^{-3}\right)$. The ratios of As to $\mathrm{Cr}(0.8-1.1)$ after the burning of fireworks (Oct. 26-27) were significantly lower than that (3.5) during the pre-BFF day (Oct. 25). An annual mean ratio (0.3) of As $\left(2.4 \mathrm{ng} \mathrm{m}^{-3}\right)$ to $\mathrm{Cr}\left(9.1 \mathrm{ng} \mathrm{m}^{-3}\right)$ for $\mathrm{PM}_{10}$ in 2013 was significantly lower than that (1.1) during the BFF day [20]. Concentrations of As during the event day were similar to the annual mean level of As, whereas $\mathrm{Cr}$ was a factor of 3.4 lower than the annual mean, indicating an insignificant contributor of fireworks to ambient $\mathrm{Cr}$ level. Like the 2012 event, all concentrations were somewhat higher during the event day than on the previous day (Oct. 25), except for As. Concentrations of $\mathrm{Pb}, \mathrm{Cr}$, and $\mathrm{Cu}$ during the event day were a factor of 1.2, 1.6, and 1.7 higher than those during the pre-BFF day. This suggested that fireworks might contribute to the enhancement in trace metal concentration. The As concentration decreased both during the event day
(50\%) and on the next day (84\%), compared to the previous day (Oct. 25).

Interestingly, the concentrations of the trace metals measured during the day after the event day dropped significantly to the levels observed during the pre-BFF day (Oct. 25), with even lower concentrations of As and Sr. This suggested that the dilution time of the air mass at the sampling site may be less than $24 \mathrm{hr}$. Compared to the 2012 event, the spatial variation of trace metal concentrations over the sampling sites was somewhat higher. The concentrations of $\mathrm{Pb}\left(37 \mathrm{ng} \mathrm{m}^{-3}\right)$ and $\mathrm{Cu}\left(26 \mathrm{ng} \mathrm{m}^{-3}\right)$ in TSP during the BFF in 2013 were somewhat higher than their annual mean concentrations in $\mathrm{PM}_{10}$ (27 and $22 \mathrm{ng} \mathrm{m}^{-3}$, resp.), whereas $\mathrm{Cd}$ concentration $\left(<0.1 \mathrm{ng} \mathrm{m}^{-3}\right)$ during the BFF in 2013 was lower than annual mean values $\left(0.4 \mathrm{ng} \mathrm{m}^{-3}\right)$. This suggested that the impact of firework events on the ambient concentration 
levels of trace metals was likely to be different depending on their chemical speciation. In this comparison, we assume that these trace metal concentrations between TSP and $\mathrm{PM}_{10}$ are not significant. According to Wang et al. [8], there was no significant difference in $\mathrm{Pb}$ and $\mathrm{Cu}$ between $\mathrm{PM}_{10}$ and $\mathrm{PM}_{2.5}$ during Lantern Festival in Beijing.

The average concentrations of the four elements $\mathrm{Al}, \mathrm{K}, \mathrm{Na}$, and $\mathrm{Ca}$ on the BFF event day were found to be $0.47 \pm 0.06$, $0.52 \pm 0.39,0.70 \pm 0.36$, and $0.85 \pm 0.12 \mu \mathrm{g} \mathrm{m}^{-3}$, respectively (Table 1). Unlike the 2012 event, the masses of the four elements were in the order $\mathrm{Ca}>\mathrm{Na}>\mathrm{K}>\mathrm{Al}$. The $\mathrm{Ca}$ concentration was a factor of 1.2-1.8 higher than the concentrations of other elements. The fractions of mineral dust during the three days (Oct. 25-27) were 13.9, 16.6, and 11.5\% of the total $\mathrm{PM}_{10}$ mass, respectively, indicating insignificant fractions of mineral dust during the pre-BFF day. In contrast to trace metal, all concentrations were generally lower during the event day than during the previous day, except for $\mathrm{K}$ (as a tracer of firework burning). The concentrations of the element $\mathrm{K}\left(0.52 \mu \mathrm{g} \mathrm{m}^{-3}\right)$ during the BFF day were somewhat enhanced by a factor of 1.72 compared to the previous day $\left(0.30 \mu \mathrm{g} \mathrm{m}^{-3}\right)$, due to the role in black powder (as the main oxidizer during burning). During the day after the event day, all concentrations decreased to below the pre-BFF concentration levels. The correlation during the study period of 2013 was generally weaker than that during the study period of 2012. In addition, very weak negative correlation between $\mathrm{Na}$ and other elements was observed in 2012, whereas significant positive correlation between $\mathrm{Na}, \mathrm{Al}$, and $\mathrm{K}$ was observed in 2013. This suggested that the sources of Na might be different from those of trace metals during the BFF day.

The mean daytime temperature and relative humidity were $16.3-17.6^{\circ} \mathrm{C}$ and $46.3-51.3 \%$, respectively. The main wind direction and mean wind speed during the night of the event day were NW (and SW) and $0.9 \mathrm{~m} \mathrm{~s}^{-1}$, respectively. The mean temperature during the nighttime was $4.3-5.0^{\circ} \mathrm{C}$ lower than that during the daytime, while the relative humidity was $12.6-$ $16.9 \%$ higher. Since wind speeds during the nighttime were relatively calm $\left(0.3-1.6 \mathrm{~m} \mathrm{~s}^{-1}\right)$, the trace metals after firework burning might not be widely dispersed.

Unlike the previous events, the $\mathrm{PM}_{10}$ concentrations at the Al site during the nighttime of the event day $\left(35.2 \mu \mathrm{g} \mathrm{m}^{-3}\right)$ appeared to be similar to those during the daytime $\left(34.6 \mu \mathrm{g} \mathrm{m}^{-3}\right)$. In addition, the $\mathrm{PM}_{10}$ concentrations during the daytime of the next day $\left(40.3 \mu \mathrm{g} \mathrm{m}^{-3}\right)$ were higher than those during the nighttime of the event day. In contrast to the 2012 event, the effect of fireworks on $\mathrm{PM}_{10}$ concentration was shown in some areas (downwind) of Busan, though the magnitude was somewhat low (up to $6 \mu \mathrm{g} \mathrm{m}^{-3}$ increase) (Figure 4). For instance, during the nighttime of the event, moderate increases of the $\mathrm{PM}_{10}$ occurred mainly in the areas to the northwest of DB, whereas large (or moderate) decreases $\left(2-20 \mu \mathrm{g} \mathrm{m}^{-3}\right.$ ) of the $\mathrm{PM}_{10}$ occurred in most other areas of Busan. On average, the monthly $\mathrm{PM}_{10}$ concentrations during the nighttime and daytime for Oct. 2013 were $36.4 \mu \mathrm{g} \mathrm{m}^{-3}$ and $40.4 \mu \mathrm{g} \mathrm{m}^{-3}$, respectively. Therefore, the increase of $\mathrm{PM}_{10}$ concentration at the northwest areas was likely due mainly to the fireworks.
The concentration differences were likely related in part to the meteorological conditions for each event (Figure 5). For instance, the main wind direction for the 2011 event did not change the next day, whereas that for the 2012 event changed from NW to SW on the next day (with some influence of SE wind). However, the main wind direction for the 2013 event changed from NW to SW on the next day, without influence of other wind directions. As shown in Figure 1, SW wind may have the potential to increase the $\mathrm{PM}_{10}$ concentration due to the anthropogenic sources near the sampling site, whereas SE wind can carry coarse particles of marine origin to some extent, causing lower fractions of fine particles. Meanwhile, annual mean concentrations of $\mathrm{PM}_{10}$ in Busan during 2000 to 2013 ranged from $43(2012)$ to $62(2000) \mu \mathrm{g} \mathrm{m}^{-3}$ with a downward trend (a slope of $-1.48 \mu \mathrm{g} \mathrm{m}^{-3} \mathrm{yr}^{-1}, r^{2}=0.76$ ) [21]. Thus, the burning of fireworks might become a significant contributor to ambient $\mathrm{PM}_{10}$ levels in the future due to a long-term downward trend of $\mathrm{PM}_{10}$.

Like the 2011 and 2012 events, the $\mathrm{O}_{3}$ concentrations during the nighttime of the event day (32 ppb) were also similar to those during the daytime (36 ppb). This unique similarity in the $\mathrm{O}_{3}$ concentrations between daytime and nighttime of the event day might be related in part to the primary emission of $\mathrm{O}_{3}$ without $\mathrm{NO}_{x}$ participation [6].

3.4. Comparison of BFF with Other Major Festivals of the World. The magnitudes of trace metal enhancement during the BFF events were much smaller compared to the Diwali festival in India, wherein a tendency of trace metal enhancement was observed (Table 2). For instance, the concentrations of $\mathrm{Ba}, \mathrm{K}, \mathrm{Al}$, and Sr during the Diwali festival (Hyderabad and Delhi) were several tens of times up to 3 orders of magnitude higher than the background values [17, 22]. Significant enhancement of elemental carbon $\left(40.5 \mu \mathrm{g} \mathrm{m}^{-3}, 4.3\right.$ times) and $\mathrm{PM}_{10}\left(753 \mu \mathrm{g} \mathrm{m}^{-3}, 2.49\right.$ times) was also observed during the Diwali festival, and firework aerosol contributed 23$33 \%$ to the ambient $\mathrm{PM}_{10}[4,17,19]$. However, the $\mathrm{PM}_{10}$ concentrations at the $\mathrm{A} 1$ sites observed herein during the BFF events were not higher than the urban (Busan) background levels, due in part to interference from local anthropogenic sources and the long distance $(2 \mathrm{~km})$ from the fireworks burst. This suggested that the burning of fireworks might be an insignificant source of $\mathrm{PM}_{10}$ at the $\mathrm{A} 1$ site.

During the Lantern Festival in Beijing, the concentrations of primary inorganic components such as $\mathrm{Ba}, \mathrm{K}, \mathrm{Sr}, \mathrm{Cl}^{-}, \mathrm{Pb}$, and $\mathrm{Mg}$ as well as secondary organic components such as oxalate, malonate, succinate, and glutarate were reported to be over five times higher than those in the preevent days [8]. The primary inorganic components and secondary organic components during fireworks were mainly in the fine and coarse modes, respectively [8]. The impact of fireworks on the physical characteristics of aerosol particles such as the number concentration of small accumulation modes (100$500 \mathrm{~nm}$ ) causing a clear shift of the particles from nucleation and Aitken mode to small accumulation mode at the peak of the fireworks event was also reported [23]. Notably, elevated levels of $\mathrm{K}, \mathrm{Al}, \mathrm{Ti}, \mathrm{Mg}, \mathrm{Pb}, \mathrm{Ba}, \mathrm{Sr}, \mathrm{Cu}$, and $\mathrm{Sb}$ (up to 3 times) were also observed during Las Fallas in Spain [3]. In addition, 
TABLE 2: Comparison of chemical components and elemental concentrations of particles during fireworks events.

\begin{tabular}{|c|c|c|c|c|c|c|c|}
\hline & Diwali India & Lantern Festival & Las Fallas Valencia & World Cup Milan & New Year Mainz & July 4 , USA & This study \\
\hline $\mathrm{PM}_{10}$ & 507 & 466 & 42 & $46-71$ & & $8\left(\mathrm{PM}_{2.5}\right)$ & $20-35$ \\
\hline $\mathrm{SO}_{4}{ }^{2-}$ & & & 8.3 & $2.7-5.1$ & 36 & & \\
\hline $\mathrm{NO}_{3}^{-}$ & & & & $<0.4-4.5$ & 6.5 & & \\
\hline $\mathrm{NH}_{4}^{+}$ & & & 1.2 & $0.9-2.5$ & 2.4 & & \\
\hline $\mathrm{OC}$ & & & $10(\mathrm{OM}+\mathrm{EC})$ & $7.9-13$ & & & \\
\hline $\mathrm{EC}$ & & & $10(0121+2 C)$ & $1.3-5.4$ & & 1 & \\
\hline $\mathrm{Fe}$ & 6 & 5 & 0.4 & $0.5-1.7$ & & 30 & \\
\hline $\mathrm{Na}$ & 14 & 4 & 0.3 & & & 0.05 & $0.7-2.3$ \\
\hline $\mathrm{Mg}$ & 21 & 6 & 0.5 & $<0.1-0.6$ & & 42 & \\
\hline $\mathrm{Al}$ & 38 & 10 & $1.8\left(\mathrm{Al}_{2} \mathrm{O}_{3}\right)$ & $0.4-0.7$ & & 92 & $0.3-0.5$ \\
\hline $\mathrm{Si}$ & & & & $0.8-1.8$ & & 0.07 & \\
\hline S & 53 & 40 & & $0.8-1.8$ & & 0.5 & \\
\hline $\mathrm{Cl}$ & 6 & 20 & & $<0.07-0.2$ & 5.1 & & \\
\hline K & 47 & 50 & 5 & $0.2-1.0$ & 33 & 0.9 & $0.4-0.5$ \\
\hline $\mathrm{P}$ & 1.4 & 0.3 & 0.07 & & & & \\
\hline $\mathrm{Ca}$ & 17 & 7 & 1.1 & $0.3-1.5$ & & 0.03 & $0.8-1.0$ \\
\hline Ti ng & 1700 & & 50 & $28-53$ & & 15 & \\
\hline $\mathrm{V}$ & 330 & & 12 & $<6$ & & 8 & \\
\hline $\mathrm{Cr}$ & 290 & & 1.9 & $<4-11$ & & & $2.7-12.7$ \\
\hline $\mathrm{Mn}$ & 930 & 400 & & $7-35$ & & 3 & \\
\hline Sn & & & 12 & & & & \\
\hline $\mathrm{Ni}$ & 70 & & 2.8 & $2-7$ & & & \\
\hline $\mathrm{Cu}$ & 550 & 600 & 64 & 20-105 & & 4 & $15-28$ \\
\hline $\mathrm{Zn}$ & 820 & 3000 & 38 & $82-276$ & & 8 & \\
\hline $\mathrm{Br}$ & 7 & & & $4-12$ & & 2 & \\
\hline $\mathrm{Pb}$ & 360 & 1100 & 244 & $9-57$ & & 8 & $21-44$ \\
\hline $\mathrm{Sr}$ & 140 & 800 & 82 & $<3-139$ & & 9 & $6-14$ \\
\hline $\mathrm{Ba}$ & 16800 & 4500 & 303 & $<20-156$ & & 28 & \\
\hline $\mathrm{Sb}$ & & & 49 & & & & \\
\hline
\end{tabular}

Diwali, 2009, Delhi, Lantern Festival, 2006, Beijing, China; India; Las Fallas, 2005, Valencia, Spain; FIFA World Cup victory, 2006, Milan, Italy; New Year, 2005, Mainz, Germany; Independence Day, 1990, Washington State, USA.

during the firework event in Milan (Italy) for the celebration of wining the football World Cup (2006), enhancement of the Sr (120 times), Mg (22 times), Ba (12 times), K (11 times), and $\mathrm{Cu}$ (6 times) metal concentrations was reported [24]. Although the sampling time ( $24 \mathrm{hr}: 11 \mathrm{am}$ to $11 \mathrm{am}$ ) in the present study was relatively long, the enhancement of some trace metals and elements was within the same orders of magnitude compared to the literature.

3.5. Emission of Trace Metals and Elements during the BFF Events. In 2012, 26,447 fireworks were used, while the amount used in 2013 increased by 37\% (36,176) compared to 2012 (Supplementary Table 1). Aerial shell type fireworks made up $29 \%(8,245)-31 \%(10,316)$ of the total fireworks, with diameters of 3-25 inches and the dominant size of 56 inches. The charge quantities of aerial shells are linearly dependent on their diameters $\left(0.03-3 \mathrm{~kg} \mathrm{shot}^{-1}\right)$. Fireworks such as igniter, mine, comet, row, and Niagara Fall (2,060$10,000)$ were also used significantly during the events. In order to assess the uncertainties of emission estimates of trace metals after firework burning, the best emission estimates were calculated using average values of the emission factors obtained from Croteau et al. 2010, while the maximum and minimum emission estimates were obtained using the lowest and highest emission factors among the four types of fireworks, respectively.

The largest metal emission during the events was K (128$164 \mathrm{~kg}$ ), followed by $\mathrm{Pb}, \mathrm{Cd}, \mathrm{Cu}, \mathrm{Mg}, \mathrm{Ba}, \mathrm{As}, \mathrm{Al}, \mathrm{Ga}, \mathrm{Co}$, and $\mathrm{Na}$ (Table 4). Emissions of other trace metals and elements were less than $1 \mathrm{~kg}$. The total emissions of trace metals and elements during the 2013 event were a factor of 1.28 higher than those during the 2012 event. Interestingly, enhancement of the $\mathrm{Pb}$ concentration by a factor of 2.91 during the 2012 event was supported by the current emission strength of $\mathrm{Pb}$. Meanwhile, the annual anthropogenic emissions of $\mathrm{Zn}, \mathrm{Pb}$, $\mathrm{Ni}, \mathrm{Co}, \mathrm{Sb}, \mathrm{Na}, \mathrm{Cd}$, and $\mathrm{K}$ in Korea during the year 2011 were reported to be $89,19,13,8,6,1.9,0.2$, and 0.01 tons, respectively (http://ncis.nier.go.kr/prtr/index.do). In general, firework burning might be an insignificant contributor to the 
TABLE 3: Correlation between elements over the study period in 2012 (Oct. 27-Oct. 29)-2013 (Oct. 25-Oct. 27).

(a) 2012

\begin{tabular}{|c|c|c|c|c|c|c|c|c|c|}
\hline $\mathrm{Pb}$ & $\mathrm{Cd}$ & $\mathrm{Cr}$ & $\mathrm{Cu}$ & As & $\mathrm{Al}$ & K & $\mathrm{Na}$ & $\mathrm{Ca}$ & $\mathrm{Sr}$ \\
\hline $\mathrm{Pb}$ & - & 0.722 & 0.908 & - & 0.847 & 0.469 & -0.366 & 0.795 & 0.669 \\
\hline $\mathrm{Cd}$ & & - & - & - & - & - & - & - & - \\
\hline $\mathrm{Cr}$ & & & 0.462 & - & 0.615 & 0.513 & -0.428 & 0.564 & 0.295 \\
\hline $\mathrm{Cu}$ & & & & - & 0.832 & 0.299 & -0.300 & 0.801 & 0.737 \\
\hline As & & & & & - & - & - & - & - \\
\hline $\mathrm{Al}$ & & & & & & 0.535 & -0.516 & 0.987 & 0.808 \\
\hline $\mathrm{K}$ & & & & & & & -0.088 & 0.513 & 0.521 \\
\hline $\mathrm{Na}$ & & & & & & & & -0.419 & 0.051 \\
\hline $\mathrm{Ca}$ & & & & & & & & & 0.869 \\
\hline $\mathrm{Sr}$ & & & & & & & & & \\
\hline
\end{tabular}

-: correlation coefficients between $\mathrm{Cd}$, As, and other elements were not available due to being below detection limit levels for $\mathrm{Cd}$ and $\mathrm{As}$.

(b) 2013

\begin{tabular}{|c|c|c|c|c|c|c|c|c|c|}
\hline $\mathrm{Pb}$ & $\mathrm{Cd}$ & $\mathrm{Cr}$ & $\mathrm{Cu}$ & As & $\mathrm{Al}$ & $\mathrm{K}$ & $\mathrm{Na}$ & $\mathrm{Ca}$ & $\mathrm{Sr}$ \\
\hline $\mathrm{Pb}$ & - & -0.034 & 0.547 & - & 0.174 & 0.395 & 0.106 & 0.135 & 0.366 \\
\hline $\mathrm{Cd}$ & & - & - & - & - & - & - & - & - \\
\hline $\mathrm{Cr}$ & & & 0.522 & - & 0.362 & 0.574 & 0.504 & 0.145 & 0.496 \\
\hline $\mathrm{Cu}$ & & & & - & -0.096 & 0.468 & 0.179 & -0.131 & 0.379 \\
\hline As & & & & & - & - & - & - & - \\
\hline $\mathrm{Al}$ & & & & & & 0.500 & 0.827 & 0.934 & 0.445 \\
\hline K & & & & & & & 0.722 & 0.333 & 0.946 \\
\hline $\mathrm{Na}$ & & & & & & & & 0.756 & 0.613 \\
\hline $\mathrm{Ca}$ & & & & & & & & & 0.286 \\
\hline $\mathrm{Sr}$ & & & & & & & & & \\
\hline
\end{tabular}

-: correlation coefficients between $\mathrm{Cd}$, As, and other elements were not available due to being below detection limit levels for $\mathrm{Cd}$ and As.

national atmospheric emissions. However, firework burning might be a predominant emission source of airborne K.

\section{Summary and Conclusions}

We analyzed the impact of large-scale firework burning on urban background trace metal and elemental concentrations and estimated their emission rates during the October month of 2011-2013. During the 2011 BFF event, trace metal concentrations were not higher than those of the previous day. In contrast, the concentrations of trace metals and elements during the BFF event days of 2012-2013 were higher than those during the pre-BFF days. The enhancement of local background concentrations of trace metals was as follows: K (1.72 times), Sr (2.64 times), As (2.86 times), $\mathrm{Pb}$ (2.91 times), and $\mathrm{Al}$ (5.44 times). Dispersion patterns of the trace metals and elements after firework burning might be significantly different due to the meteorological conditions, indicating different impact on their concentration levels according to geographic location. In addition, the impact of firework events on the ambient concentration levels for trace metals was likely to be different depending on their chemical speciation. In general, firework metals during
TABLE 4: Estimated emissions of trace metals from the BFF during the study periods (in $\mathrm{kg}$ ).

\begin{tabular}{lcccccc}
\hline Elements & & 2012 & & & 2013 & \\
& Max. & Min. & Best & Max. & Min. & Best \\
\hline $\mathrm{TSP}$ & 502.762 & 240.608 & 393.578 & 644.490 & 308.435 & 504.946 \\
$\mathrm{~K}$ & 161.602 & 82.597 & 127.829 & 207.158 & 105.881 & 164.064 \\
$\mathrm{Mg}$ & 24.420 & 4.669 & 12.052 & 31.304 & 5.985 & 15.424 \\
$\mathrm{Ba}$ & 22.624 & 0.108 & 8.284 & 29.002 & 0.138 & 10.707 \\
$\mathrm{Na}$ & 4.309 & 0.205 & 1.098 & 5.524 & 0.262 & 1.403 \\
$\mathrm{Ca}$ & 2.478 & 0.079 & 0.323 & 3.176 & 0.101 & 0.413 \\
$\mathrm{Cu}$ & 28.370 & 0.162 & 15.754 & 36.368 & 0.207 & 20.157 \\
$\mathrm{Al}$ & 6.823 & 2.729 & 4.471 & 8.747 & 3.499 & 5.727 \\
$\mathrm{~Pb}$ & 96.961 & 0.007 & 36.903 & 124.295 & 0.009 & 47.664 \\
$\mathrm{Ga}$ & 5.028 & 0.017 & 1.853 & 6.445 & 0.022 & 2.394 \\
$\mathrm{Sr}$ & 2.550 & 0.031 & 0.249 & 3.268 & 0.039 & 0.318 \\
$\mathrm{Zn}$ & 2.262 & 0.086 & 0.723 & 2.900 & 0.110 & 0.936 \\
$\mathrm{Fe}$ & 2.011 & 0.151 & 0.807 & 2.578 & 0.193 & 1.031 \\
$\mathrm{Bi}$ & 1.939 & 0.000 & 0.618 & 2.486 & 0.000 & 0.787 \\
$\mathrm{P}$ & 0.190 & 0.040 & 0.095 & 0.244 & 0.051 & 0.121 \\
$\mathrm{Mn}$ & 0.140 & 0.036 & 0.083 & 0.180 & 0.046 & 0.106 \\
$\mathrm{Ti}$ & 0.255 & 0.010 & 0.060 & 0.327 & 0.013 & 0.077 \\
$\mathrm{Cr}$ & 0.431 & 0.006 & 0.139 & 0.552 & 0.008 & 0.178 \\
$\mathrm{Sn}$ & 0.072 & 0.001 & 0.029 & 0.092 & 0.001 & 0.037 \\
$\mathrm{Si}$ & 1.257 & 0.014 & 0.402 & 1.611 & 0.018 & 0.514 \\
$\mathrm{Cr}{ }^{6+}$ & 0.043 & 0.001 & 0.024 & 0.055 & 0.001 & 0.031 \\
$\mathrm{Rb}$ & 0.032 & 0.012 & 0.021 & 0.041 & 0.015 & 0.027 \\
$\mathrm{Sb}$ & 0.019 & 0.000 & 0.007 & 0.024 & 0.000 & 0.010 \\
$\mathrm{~V}$ & 0.169 & 0.001 & 0.021 & 0.216 & 0.002 & 0.026 \\
$\mathrm{Te}$ & 0.025 & 0.000 & 0.010 & 0.032 & 0.000 & 0.013 \\
$\mathrm{Co}$ & & & 1.594 & & & 2.076 \\
$\mathrm{As}$ & & & 4.787 & & & 6.232 \\
$\mathrm{Cd}$ & & & 23.967 & & & 31.204 \\
$\mathrm{Total}$ & 866.77 & 331.57 & 635.78 & 1111.12 & 425.04 & 816.62 \\
\hline & & & & & &
\end{tabular}

the study period exhibited significant positive correlation, pointing their common source. During the $2012 \mathrm{BFF}$ event, the effect of the fireworks caused moderate increases (at least up to $10 \mu \mathrm{g} \mathrm{m}^{-3}$ ) of $\mathrm{PM}_{10}$ (as a proxy for trace metal dispersion) concentrations in all areas of Busan. In contrast, the increase of $\mathrm{PM}_{10}$ concentrations (up to $6 \mu \mathrm{g} \mathrm{m}^{-3}$ increase) during the nighttime of the 2013 BFF event occurred only at the northwest areas influenced directly by the fireworks. In general, the concentrations of the trace metals and elements examined during the day after the event dropped significantly to the levels observed during the pre-BFF day, suggesting lifetimes of one day or so. The impact of firework burning on the $\mathrm{PM}_{10}$ concentration varied depending on the event day and locations. This suggested that the $\mathrm{PM}_{10}$ concentrations at the measurement sites were likely affected by metrological conditions and local anthropogenic sources, such as on-road mobile sources. The burning of fireworks might become a significant contributor to ambient $\mathrm{PM}_{10}$ levels in the future due to a long-term downward trend of $\mathrm{PM}_{10}$. 
Various types of fireworks such as aerial shell, mine, comet, row, and Niagara Fall (26,447 for 2012 BFF and 36,176 for $2013 \mathrm{BFF}$ ) were used during the BFF event days, which have diverse burst heights (up to $500 \mathrm{~m}$ ) and sizes (up to $400 \mathrm{~m}$ ). Of the trace metals, the emissions of $\mathrm{K}$ (128-164 kg), Pb (37-48), Cd (24-31), Cu (16-20), and Mg (12-15) were significant. In general, firework burning might be an insignificant contributor to the national atmospheric emissions of trace metals, except for K. In future study, the emission factors of trace metals for the burning of a various types of firework, which is the major contributor to the uncertainty in emission estimates, should be examined to reduce the uncertainties. In the future study, the atmospheric dispersion of trace metals during the burning of fireworks will be simulated by a high-resolution dispersion model such as Computational Fluid Dynamics (CFD) model using the emission rates of trace metals estimated in this study.

\section{Conflict of Interests}

The authors declare that there is no conflict of interests regarding the publication of this paper.

\section{Acknowledgment}

The authors greatly appreciate Dr. Park G. H. from Busan Metropolitan City Institute of Health \& Environment for the provision of the valuable data set of trace metals measured during the firework events.

\section{References}

[1] Agency for Toxic Substances and Disease Registry (ATSDR), "Toxicological profile information sheet," 2003, http://www .atsdr.cdc.gov/toxprofiles.

[2] X. Wang, X. Bi, G. Sheng, and J. Fu, "Hospital indoor PM10/ PM2.5 and associated trace elements in Guangzhou, China," Science of the Total Environment, vol. 366, no. 1, pp. 124-135, 2006.

[3] T. Moreno, X. Querol, A. Alastuey et al., "Recreational atmospheric pollution episodes: inhalable metalliferous particles from firework displays," Atmospheric Environment, vol. 41, no. 5, pp. 913-922, 2007.

[4] S. C. Barman, R. Singh, M. P. S. Negi, and S. K. Bhargava, "Ambient air quality of Lucknow City (India) during use of fireworks on Diwali Festival," Environmental Monitoring and Assessment, vol. 137, no. 1-3, pp. 495-504, 2008.

[5] O. Fleischer, H. Wichmann, and W. Lorenz, "Release of polychlorinated dibenzo-p-dioxins and dibenzofurans by setting off fireworks," Chemosphere, vol. 39, no. 6, pp. 925-932, 1999.

[6] A. K. Attri, U. Kumar, and V. K. Jain, "Formation of ozone by fireworks," Nature, vol. 411, no. 6841, p. 1015, 2001.

[7] J. H. Mclain, Pyrotechnics from the Viewpoint of Solid State Chemistry, The Franklin Institute Press, 1980.

[8] Y. Wang, G. Zhuang, C. Xu, and Z. An, "The air pollution caused by the burning of fireworks during the lantern festival in Beijing," Atmospheric Environment, vol. 41, no. 2, pp. 417-431, 2007.
[9] J. A. Conkling, Chemistry of Pyrotechnics: Basic Principles and Theory, Marcel Dekker, New York, NY, USA, 1985.

[10] N. Passant, "Emission factors programme Task 1-summary of simple desk studies," Appendix 1: Fireworks Briefing Note AEAT/ENV/R/1421, Department of Environment, Food and Rural Affairs, London, UK, 2003.

[11] G. Croteau, R. Dills, M. Beaudreau, and M. Davis, "Emission factors and exposures from ground-level pyrotechnics," Atmospheric Environment, vol. 44, no. 27, pp. 3295-3303, 2010.

[12] W. C. Skamarock, J. Klemp, J. Dudhia et al., "A description of the advanced research WRF version 3," NCAR Technical Note NCAR/TN-468+STR, Mesoscale and Micro scale Meteorology Division, National Center for Atmospheric Research, Boulder, Colo, USA, 2008.

[13] Busan Metropolitan City Institute of Health \& Environment (BMCIHE), "Report of air quality in Busan 2011," Tech. Rep., 2012.

[14] T.-M. Do, C.-F. Wang, Y.-K. Hsieh, and H.-F. Hsieh, "Metals present in ambient air before and after a firework festival in Yanshui, Tainan, Taiwan," Aerosol and Air Quality Research, vol. 12, no. 5, pp. 981-993, 2012.

[15] T. Moreno, X. Querol, A. Alastuey et al., "Effect of fireworks events on urban background trace metal aerosol concentrations: is the cocktail worth the show?" Journal of Hazardous Materials, vol. 183, no. 1-3, pp. 945-949, 2010.

[16] Busan Metropolitan City Institute of Health \& Environment (BMCIHE), Report of Air Quality in Busan 2012, Busan Metropolitan City Institute of Health \& Environment (BMCIHE), 2013.

[17] S. Sarkar, P. S. Khillare, D. S. Jyethi, A. Hasan, and M. Parween, "Chemical speciation of respirable suspended particulate matter during a major firework festival in India," Journal of Hazardous Materials, vol. 184, no. 1-3, pp. 321-330, 2010.

[18] S. M. McLennan, "Relationships between the trace element composition of sedimentary rocks and upper continental crust," Geochemistry, Geophysics, Geosystems, vol. 2, no. 4, 2001.

[19] D. P. Singh, R. Gadi, T. K. Mandal et al., "Study of temporal variation in ambient air quality during Diwali festival in India," Environmental Monitoring and Assessment, vol. 169, no. 1-4, pp. $1-13,2010$.

[20] Busan Metropolitan City Institute of Health \& Environment (BMCIHE), "Report of air quality in Busan 2013," Tech. Rep., 2014.

[21] National Institute of Environmental Research (NIER), Annual Report of Air Quality in Korea 2013, National Institute of Environmental Research (NIER), 2014.

[22] U. C. Kulshrestha, T. Nageswara Rao, S. Azhaguvel, and M. J. Kulshrestha, "Emissions and accumulation of metals in the atmosphere due to crackers and sparkles during Diwali festival in India," Atmospheric Environment, vol. 38, no. 27, pp. 44214425, 2004.

[23] M. Zhang, X. Wang, J. Chen et al., "Physical characterization of aerosol particles during the Chinese New Year's firework events," Atmospheric Environment, vol. 44, no. 39, pp. 5191-5198, 2010.

[24] R. Vecchi, G. Marcazzan, and G. Valli, "A study on nighttimedaytime PM10 concentration and elemental composition in relation to atmospheric dispersion in the urban area of Milan (Italy)," Atmospheric Environment, vol. 41, no. 10, pp. 2136-2144, 2007. 

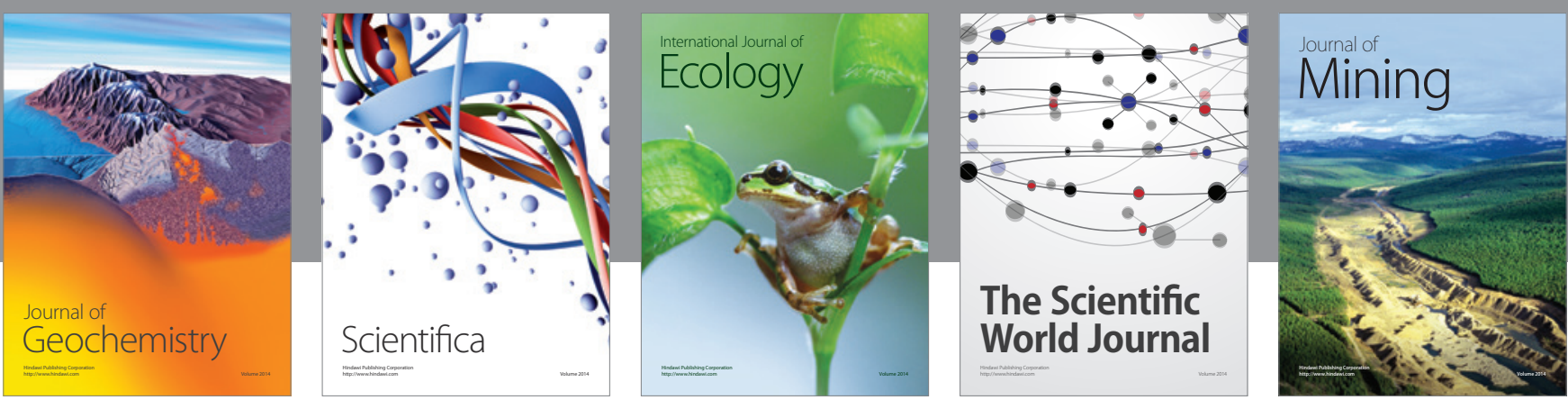

The Scientific World Journal
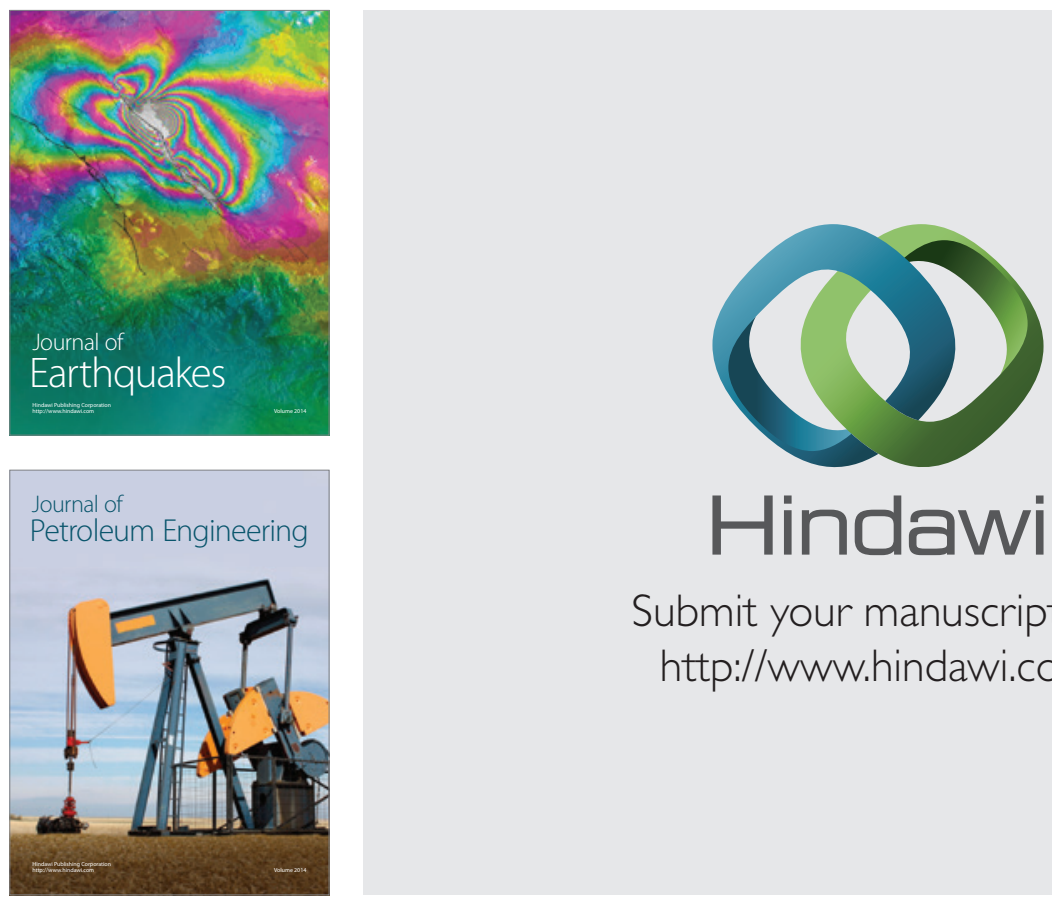

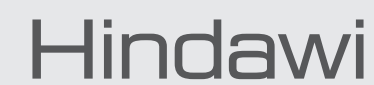

Submit your manuscripts at

http://www.hindawi.com
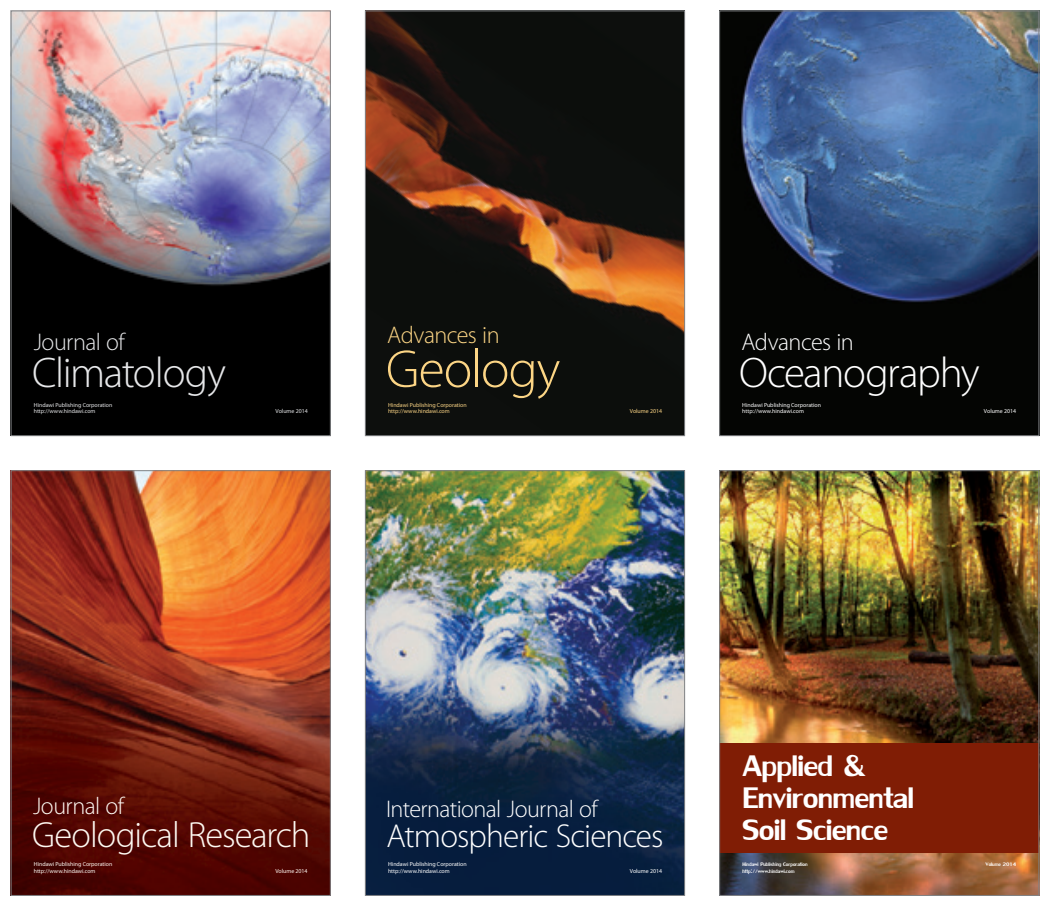
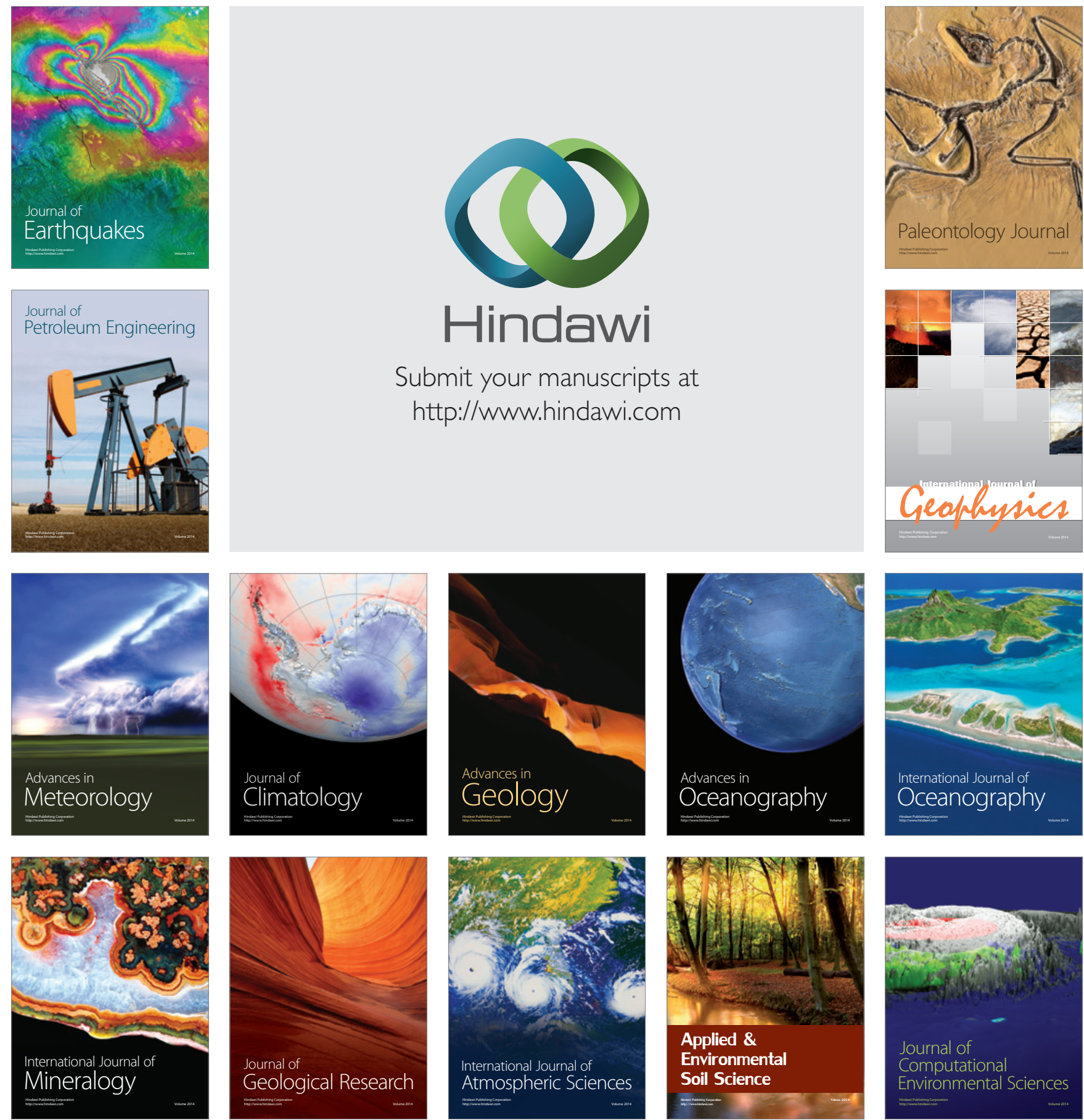